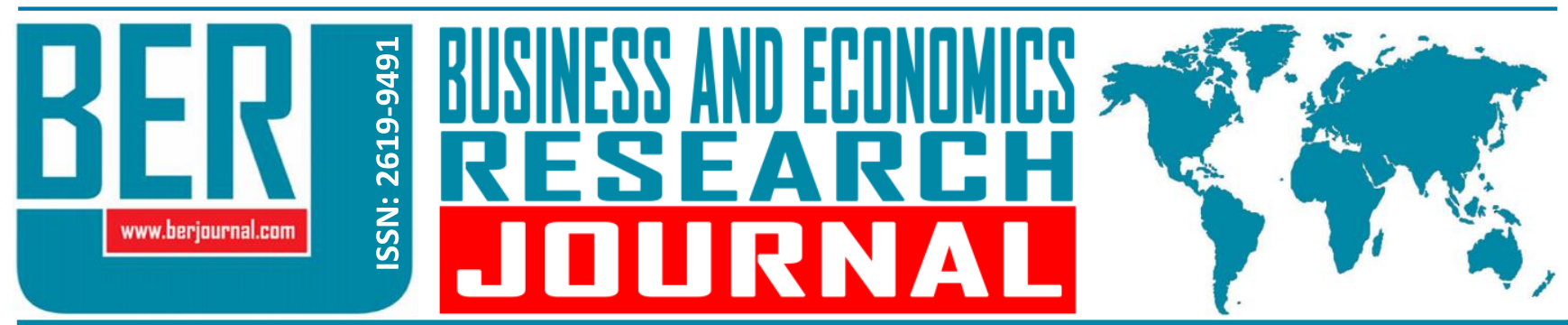

Business and Economics Research Journal Vol. 12, No.1, $2021 \quad$ pp. 127-144 doi: 10.20409/berj.2021.314

\title{
Ekonomik Daralma Dönemlerinde Likidite Kıtlığı ve Ticari Borç Yönetimi
}

\section{Bahadir Karakoc ${ }^{a}$}

Öz: Bu çalışmada, halka açık işletmelerin ticari kredi politikaları 17 ülkeden yaklaşık 11.000 firmanın verisi kullanılarak incelenmiştir. Bulgular tedarikçi finansmanının en çok, nakit darlığı içerisinde olan firmalar tarafından tercih edildiğini ve ekonominin yavaşladığı dönemlerde bu talebin daha da arttığını göstermektedir. Benzer bulgular ticari borçların vadesi için de geçerlidir. Ülkeler, gelişmiş ve gelişmekte olan şeklinde gruplara ayrıldığında bulgular farklılaşmakta olup sıkıntılı dönemlerde gelişmekte olan ülke firmaları ticari borçların miktarını arttırıp vadesini uzatırken, gelişmiş ülkelerde tam tersi sonuçlar elde edilmiştir. Bulguların güvenilirliğini arttırmak amaçlı hem 2008 finansal krizi hem de ekonomik daralma dönemleri mercek altına alınmıştır. Sonuçlar özellikle düşük likiditeye sahip firmaların sıkıntılı dönemlerde daha fazla tedarikçi finansmanını daha uzun süre kullanmak suretiyle süreci atlatabildiklerini göstermektedir.

\section{Trade Credit Policies and Shortage of Liquidity in Cycles of Economic Contraction}

Abstract: This study examines the trade credit practices of 11.000 publicly listed firms from 17 countries ( 9 developed and 8 developing). The results indicate that firms with a lack of short-term liquidity receive more trade credit for a longer duration. It becomes even more pronounced in times of economic contraction. For robustness, both the period of the 2008 financial crisis and a contractionary period are scrutinized. A slowdown in the economy creates opposing effects on firms from developed and developing countries, while the former use less credit for a shorter period; the latter receive more credit for a longer period of time, whereas firms with a shortage of liquidity behave similarly, i.e., they increase the amount and the duration of trade credit. The findings suggest that firms with a lack of liquidity survive troubling times by obtaining more trade credit from their suppliers.
Anahtar Sözcükler: Ticari Borçlar, Ekonomik Daralma, Nakit Yönetimi, Alternatif Finansman Kaynağı

JEL: G30, G31, G32

$\begin{array}{ll}\text { Geliş } & : 18 \text { Eylül } 2020 \\ \text { Düzeltme } & : 01 \text { Aralık } 2020 \\ \text { Kabul } & : 15 \text { Ocak } 2021 \\ \text { Tür } & : \text { Araştırma }\end{array}$

Keywords: Trade Credit, Economic Contraction, Cash Management, Alternative Financing Instruments

JEL: G30, G31, G32

Received : 18 September 2020 Revised : 01 December 2020 Accepted : 15 January 2021

Type : Research

a Asst. Prof., PhD., Mus Alparslan University, Faculty of Economics and Administrative Sciences, Department of International Trade and Business, Mus, Turkiye, b.karakoc@alparslan.edu.tr (ORCID ID: 0000-0001-8137-2233) 


\section{Giriş}

Ticari krediler (bundan sonra TK olarak kullanılmıştır) en basit tanımı ile satıcının alıcıya sattığı malı vadeli satması olarak tanımlanabilir. Teslimat ile ödeme tarihi arasındaki süre satıcıya malı nakde çevirmesi ve faaliyetlerinde kullanması açısından likidite sağlamaktadır. Akademik literatürde pek çok teorik ve ampirik çalışmada dile getirildiği üzere ilişkinin temelinde iş ortakları arasındaki bilgi doygunluğu (Biais ve Gollier, 1997; Agostino ve Triveri, 2014) ve satışları artırma çabası vardır (Petersen ve Rajan, 1997; Karakoç, 2020). Özellikle uzun vadeli taahhüt gerektiren durumlarda tarafların kârlılı̆ı ve nakit akış süreçleri birbirlerine bağı olduğu sürece (Cunat, 2007) ve iş ortaklarının kredi sağlayarak elde edecekleri fayda kredinin maliyetinin üzerinde olduğu sürece TK desteği sürecektir (Garcia-Appendini ve Montroiel-Garriga, 2013). Bu açıdan bakıldığında TK önemli bir finansal kaynak olarak karşımıza çıkmaktadır. Nitekim literatür TK'nin firmaların ihtiyaç halinde faydalandıkları alternatif bir finansman aracı olduğunu ortaya koyan pek çok çalışmayı barındırmaktadır. Ticari kredilerin ekonomik küçülme dönemlerinde üstlendiği rol bazı çalışmalara konu olmuş olsa da bu çalışmalar genellikle Amerika Birleşik Devletleri (ABD) ve Avrupa kıtasındaki gelişmiş ülkeleri (bkz. Garcia-Appendini ve Montoriol-Garriga, 2013; McGuinness vd., 2018) ya da sadece KOBi türünde özel işletmeleri hedef almıştır (bkz. Valverde vd., 2016). Bu açıdan bakıldığında literatürün gelişen ülke verileri üzerinden yapılmış çalışmalara da ihtiyacı olduğu açıktır, zira gelişmekte olan ülkelerin finans sistemlerinin göreceli olarak daha zayıf olması, firmaları daha çok ticari kredi odaklı büyüme modellerine yöneltmiştir (Fisman ve Love, 2003). Bahsi geçen çalışmalarda genellikle TK'lerin miktarındaki değişim incelenmiştir. Literatürde yeterince incelenmeyen diğer bir önemli konu ise ticari kredilerin vadesindeki değişmedir. Ekonomik daralmanın etkisi, firmalara satışlarda düşüş ve mevcut stokların nakde çevrilmesinde yavaşlama olarak yansıyacak, bunun neticesinde kısa vadeli likidite ihtiyacı ortaya çıkacaktır. Dolayısıyla ekonominin sıkıntıda olduğu dönemlerde firmalar arasındaki dayanışmanın ticari borçların vadesine nasıl yansıdığının kapsamlı bir şekilde araştırılması gerekmektedir.

Bu çalışmanın amacı, ekonomik daralma ${ }^{1}$ dönemlerinde kullanılan TK'lerin miktarlarındaki ve vadelerindeki değişimleri ampirik olarak araştırmaktır. Bunun yanı sıra, firmaların finansal tercihlerini etkileyebilecek iki önemli değişkenin de firma-hacim ve kısa vadeli likiditenin bu süreçte TK politikalarını nasıl şekillendirdiği incelenmiştir. Firmaların ticari kredi kullanma ve kullandırmaları üzerine yoğunlaşan bazı çalışmalar, örneğin Petersen ve Rajan (1997), Nilsen (2002) ve Atanasova ve Wilson (2003) firma büyüklüğünün/küçüklüğünün, diğer taraftan Garci Biais ve Gollier (1997), Garcia-Appendini ve MontroelGarriga (2013) ve Love vd. (2007) kısa vadeli likiditenin firmaların TK politikaları üzerinde belirleyici rol oynadığını göstermişlerdir. Dolayısıyla bu iki önemli değişkenin sıkıntılı dönemlerde fark yaratacak şekilde kararları etkileyip etkilemediği de araştırılmalıdır. Elde edilecek bulgular, firmaların ekonomik daralma dönemlerinde TK'leri stratejik bir enstrüman olarak kullanıp kullanmadıklarına dair dönüt vererek hem politika yapıcılara hem de uygulayıcılara yön gösterecek şekilde katkı sağlayacaktır. Çalışmanın en güçlü taraflarından biri, zengin bir veri seti ile elde edilen karşılaştırılabilir sonuçlar üretmiş olmasıdır. Gerek finansal gerekse hukuksal alandaki yapısal farklılıkların ${ }^{2}$ önem arz edebileceği dikkate alınarak gelişen ve gelişmişülke verileri ayrı ayrı incelenmiştir. Gelişmekte olan ülkelerde nispeten daha zayıf bir finansal yapı ve bunun neticesinde TK ağılıklı finansman politikaları gözlemlemek mümkündür (Fisman ve Love, 2003). Gelişmiş ülkelerde ise finansal sistem, örneğin Almanya ve Japonya'nın da dâhil olduğu banka temelli veya Amerika ve İngiltere gibi ülkelerin içinde yer aldığı piyasa temelli olarak sınıflandırılmaktadır (Demirgüç-Kunt ve Ross, 1999). Bu ayrım da firmaların TK talep ve arzlarını dikkate almaya değer ölçüde etkileyebilecektir. Özellikle banka yoğun finansal sisteme sahip ülkelerde firmalar kriz zamanları kredi bulmakta zorlanabilirler (McGuinness vd., 2018). Genel olarak örneklemdeki ülkeler gelişmişlik seviyelerine göre kategorize edilmiş olsa da grup içi değerlendirmede ülkelerarası ciddi farklııklar göze çarpmaktadır. Örneğin ortalama TK talebinin toplam varlıklara oranı \%8 ile en düşük Amerikan firmalarında iken \%16 ile en yüksek İtalyan firmalarında bulunmaktadır. Gelişmekte olan ülkelerde ise bu oran ortalama \%10 civarındadır ve grup içi oranlar daha benzerdir.

Çalışmada kullanılan veriler 2000-2014 yıllarını kapsamaktadır. Bunun nedeni örneklemdeki hem gelişmiş hem de gelişmekte olan ülkelerdeki büyüme rakamlarında sert dalgalanmalar meydana gelmiş olmasıdır. Örneğin Türkiye, Rusya ve Meksika gibi ülkelerin en büyük ve en küçük büyüme rakamları sırasıyla $\% 10, \% 11, \% 5$ ve $-\% 7,8,-\% 6,0$ ve $-\% 5,3$ 'tür. Gelişmiş ülkelerde ise büyüme rakamları daha istikrarlı olmasına rağmen 2008 krizinin etkisiyle Japonya, Almanya ve italya gibi ülkeler -\%5 civarında büyüme rakamlarını tecrübe etmişlerdir. Ekonomik aktivitedeki bu sert dalgalanmaların firmaların TK kullanımına büyük ölçüde 
yansıması beklenmektedir (Karakoç, 2020). Dolayısıyla tercih edilen periyod ve ülkeler çalışmada öne sürülen hipotezlerin test edilmesi için elverişli bir laboratuvar ortamı sağlamaktadır. Araştırmaya konu olan dönemler 2008 küresel finansal krizinin gerçekleştiği ve GSMH'nin daraldığı dönemleri ${ }^{3}$ içermektedir. Bu tür dönemlerin firma faaliyetlerine etkisi, özellikle finansman cephesindeki yankıları, finansal ekonomi literatüründe geniş yer bulmuş ve Bernanke vd. (1995) tarafından öne sürülen "financial accelerator" hipotezi ile teorileştirilmiştir. Buna göre daralma dönemlerinde firmaların teminat değerlerinde ve nakit akışlarındaki küçülme zaten zayıf olan krediye erişim olanaklarını daha da olumsuz etkileyecektir. Hem finansal krediye erişimin zorlaşması hem de nakit akışlarının cılızlaşması firmaların TK politikalarında önemli değişimlerin gerçekleşmesine neden olabilecektir. Bu nedenle, çalışmada finansal krize ek olarak 2000-2014 yılları içerisinde her ülkenin ekonomisinin en küçük büyümeyi yaşadığı üç yılda, firmaların TK talepleri incelenmiştir. Daralma dönemlerinin de çalışılmış olması hem sonuçların genellenebilirliğini hem de karşılaştırılabilmesine imkân vererek sonuçların güvenilirliğini artırmayı amaçlamaktadır.

Literatürdeki çalışmaların önemli bir çoğunluğu TK miktarı üzerine yoğunlaşmış, TK kullanım süresindeki değişim yeterince incelenmemiştir. ${ }^{5}$ Bu nedenle çalışma literatürdeki bu ihtiyacı gidermeyi hedeflemektedir. Buna ek olarak pek çok çalışma ya KOBi türünden işletmeleri konu almış ya da gelişmiş ülke piyasalarındaki firmalar üzerine odaklanmıştır. Bu çalışmada ise hem gelişmiş hem de gelişmekte olan toplam 17 ülkeden 11.000 firmanın verisi ile oldukça kapsayıcı bir veri seti kullanılarak daha genellenebilir sonuçlar elde edilmiştir. Çalışmanın katkı sağladığı bir diğer husus ise özellikle küçük ve/veya likidite sıkıntısı içerisindeki firmaların sıkıntılı dönemlerde TK politikaları sayesinde süreci atlatabildiklerini göstererek uygulayıcılara kısa vadeli kaynak yönetimi hakkında tavsiyelerde bulunmaktadır. 2008 finansal krizini inceleyen bazı çalışmalar (örneğin; de Haas ve van Lelyveld, 2010; Almeida vd., 2010) genişlemeci politika faizlerine rağmen, kredi arzının ciddi manada etkilendiğini ve bunun büyük ve güçlü firmalar tarafından da hissedildiğini ortaya koymuşlardır. Dolayısıyla içerisinde bulunduğumuz pandemi sürecine hazırlıksız yakalanan birçok işletme, tedarikçi finansmanından faydalanarak süreci daha hafif atlatabilecektir.

\section{Literatür ve Hipotezler}

Kriz dönemlerinde geleneksel banka kredi arz ve/veya talebinin olumsuz etkilenmesini beklemek mümkündür. Firmaların, normal ve ekonomik anlamda sıkıntılı dönemlerde krediye erişimde yaşayabileceği zorluklar Bernanke ve Gertler (1995), Bernanke Gertler ve Gilchrist (1996), Gertler ve Gilchrist (1994) gibi çalışmalarda detaylı bir şekilde incelenmiştir. Bu çalışmalardaki ortak tema aracı finansal kurum ve firmalar arasındaki bilgi asimetrisinin varlığı ve bunun neticesinde ortaya çıkan temsil maliyetinin krediye erişimde önemli problemlere yol açıyor olmasıdır. Temsil maliyeti ya kredi talebinin tamamen ya da kısmen reddine ya da kredinin yüksek maliyetlerle verilmesine neden olmaktadır. Firmalar için daha sıkıntı verici olanı ise bilgi asimetrisinin, dolaysıyla da krediye erişim imkânlarının ekonominin gidişatına göre daha da kötüleşebilmesidir. Örneğin daralmacı para politikalarının hâkim olduğu dönemlerde zaten azalmış olan kredi havuzu, sadece güçlü ve büyük firmalara yönlendirilecek ve bilgi asimetrisinden muzdarip firmalar kredi bulmakta güçlük çekeceklerdir (Bernanke vd., 1996). Bernanke vd. (1996) bu argümanı daha ileriye taşıyıp, bu tür dönemlerde firma gelirlerindeki azalmanın, ekonomik değer yaratma kapasitesindeki düşüşün firmanın varlıklarının teminat olarak değerini azaltacağını ve bu ikisinin etkileşiminin krediye erişim olanaklarını iyice yıpratacağını öne sürmektedirler. Bu süreci "financial accelerator" olarak tanımlamaktadırlar. Sonuç olarak, kredi bulmakta zorluk yaşayan bu firmalar mevcut likidite stoklarını tüketmek, alternatif kaynak bulmak veya yatırım harcamalarını kısmak gibi sayılı seçenek ile karşı karşıya kalacaklardır. Firmalar genellikle gelecekte elde edecekleri nakit akışlarına güvenerek borçlanır (Biais ve Gollier, 1997) ve kriz dönemlerindeki belirsizlik yatııı ve borçlanma planlarını baskılayabilir, dolayısıyla firmaların banka kredisine olan talebi de olumsuz etkilenebilir.

Bu konudaki ampirik çalışmalar da teorik altyapıyı doğrular niteliktedir. Örneğin Presbitero, Udell ve Zazzaro (2011) ve Popov ve Udell (2012), kriz sonrası nispeten zayıf bankaların kredi arzını düşürdüğünü raporlamaktadırlar. Özellikle gelişmiş ülkelerde 2008 krizi sonrası politika faizlerinin düşük olmasına rağmen reel sektörün borç seviyesinde ciddi düşüş meydana gelmiştir (bkz. IMF Global Debt Database, 2020).

Mevcut literatürde firmaların kredi kısıtı olsun ya da olmasın bu tür dönemlerde kaynak bulmada güçlük yaşayacağı düşüncesinden hareketle farklı finansal enstrümanlara olan talepleri incelenmiştir. Örneğin, Calomiris, Himmelberg ve Wachtel (1995), para politikası şoklarının ABD'deki büyük ve güçlü firmaları bono ve tahvil piyasalarına, KOBi'leri ise TK kullanımına yönlendirdiğini göstermişlerdir. Dolayısıyla 
tedarikçi kredileri pek çok firma için ortaklardan rahatlıkla tedarik edilebilen alternatif bir finansman kaynağı olarak karşımıza çıkmaktadır. Tedarikçi finansmanının alternatif olma özelliği ilk olarak Meltzer (1960) tarafından ortaya atılmıştır. Meltzer (1960) toplu kredi verilerinden elde ettiği gözlemlere dayanarak, likidite seviyesi yüksek firmaların ekonomik durgunluk dönemlerinde iş ortaklarına daha fazla TK verdiklerini öne sürmüştür. Schwartz (1974) bu tür durumlarda krediye erişimde sıkıntı yaşayan firmaların iş ortaklarına yönelebileceğini dile getirmiştir. Bu fikrin temelinde tarafların borçlanma maliyetlerinin farklı olması vardır. Dolayısıyla, eğer tedarikçi firma krediye erişim noktasında müşterisinden daha iyi bir performans sergiliyorsa ucuza mal ettiği fonları iş ortaklarına TK olarak sunabilecektir. Nitekim firmalar ortaklarına sundukları krediyi kısa vadeli fakat uzun soluklu bir iş ilişkisine yapılmış bir yatırım olarak görürler (Petersen ve Rajan, 1997; Biais ve Gollier, 1997). Örneğin, Karakoç (2020) fiziksel kapasiteye yatıım yapan firmaların iş ortaklarından negatif ekonomik koşullar altında bile destek bulabildiklerini göstermiştir. Tedarikçi firmanın motivasyon kaynağı iş ortağının faaliyetleri üzerinde uzun bir döneme yayılan getiri beklentisidir. Tedarikçilerinden kredili mal temin eden bir firma faaliyetlerine devam edebildiği ve kar elde ettiği sürece tedarikçisinin mallarını alıp satacak ve dolayısıyla yaptığı her bir liralık satış tedarikçinin satış rakamlarına da yansıyacaktır. Sonuç olarak, tarafların gelir elde etme mekanizmaları birbirlerine bağlı olduğu için, zor koşullardan geçerken bile tedarikçi firma iş ortağına destek sağlama noktasında gerekli motivasyona sahiptir.

Bunun yanı sıra tedarikçi firmanın, finansal kuruma nazaran, sattığı ürünlere teminat olarak el koyma ve çok fazla bir maliyete katlanmadan nakde çevirme avantajı bulunmaktadır. Teminat olarak el konulan ürün satıcının kendi ürünü olduğu ve satıcı ürünü ve piyasayı çok iyi bildiği için zararını giderme noktasında başarıı olacaktır. Böyle bir işlem banka için fazlasıyla maliyetli olabilecekken, satıcı firma aynı işlemi çok küçük maliyetlerle gerçekleştirebilecektir (Mian ve Smith, 1992; Frank ve Maksimovic, 1999).

Benzer bir çalışmada, Garcia-Appendini ve Montoriol-Garriga (2011) 2008 finansal krizi sonrası ABD'deki firmaların TK kullanımına olan talebini incelemişler ve firmaların daha çok TK kullandığını ortaya koymuşlardır. Valverde vd. (2016) 2008 finansal krizinin etkilerini inceledikleri çalışmalarında özellikle finansal sıkıntı içinde olan firmaların tedarikçilerine olan bağımlıı̆ının arttığını ortaya koymuşlardır. Özellikle finansal sıkıntı içinde olan KOBi türünde işletmeler için TK alternatif bir finansal kaynak oluşturmaktadır ve bu kaynağın önemi sıkıntılı dönemlerde daha da artmaktadır (Mateut vd., 1995; Nilsen, 2002). Yakın geçmişte 2008 krizi sonrasında da tecrübe edildiği üzere, parasal genişlemeye rağmen bankalar kredi vermekte çekingen davranabilmektedirler (Kazmin, Lamont ve Leahy, 2008). Kredi arzında yaşanan negatif şoklar firmaları alternatif kaynak bulmaya itmekte, sonuç olarak bu durum alternatif finansman kaynaklarının yönetimini daha da önemli kılmaktadır. Özellikle, likidite problemi yaşayan firmalar için bu konunun oldukça önem arz edeceğini söylemek mümkündür. Dolayısıyla bu çalışmada şu hipotezler test edilmiştir:

\section{$H_{1}$ : Ekonomik daralma dönemlerinde firmaların TK kullanımı artmaktadır. \\ $\mathrm{H}_{2}$ : Ekonomik daralma dönemlerinde TK'lerin vadeleri artmaktadır. \\ $\mathrm{H}_{3}$ : Kısa vadeli likidite stoğu firmaların TK politikalarını etkilemektedir. \\ $\mathrm{H}_{4}$ : Firmanın hacmi (firmanın küçük oluşu) TK politikalarını etkilemektedir.}

\section{Veri ve Yöntem}

Çalışmada kullanılan firma verileri Thomson Reuters veri sağlayıcısından, makro veriler ise Dünya Bankası web sayfasından alınmıştır. Veri aralığı 2000-2014 yılları olup, 9 gelişmiş ve 8 gelişmekte olan, toplam 17 ülkeden (bkz. Tablo 1) yaklaşık 11.000 halka açık firmanın verisini kapsamaktadır. Sabit etki panel veri analizi temel yöntem olarak benimsenmiştir. Modelin uygunluğu aşağıdaki testler uygulanarak belirlenmiştir.

Illk aşamada serilere durağanlık testi uygulanmıştır (test sonuçları için bkz. Ek.1). Veri seti dengesiz panel niteliğindedir ve her bir yatay kesitte 2000'den 2014'e kadar olan gözlemler arasında kayıplar olabilmektedir bu nedenlerden ötürü kullanılan verinin bu özelliklerini dikkate alan Fisher-type (Choi, 2001) durağanlık testi uygulanmıştır. Uygulanan testin sonuçlarına göre serilerde birim kök olduğuna dair bir bulgu yoktur. 


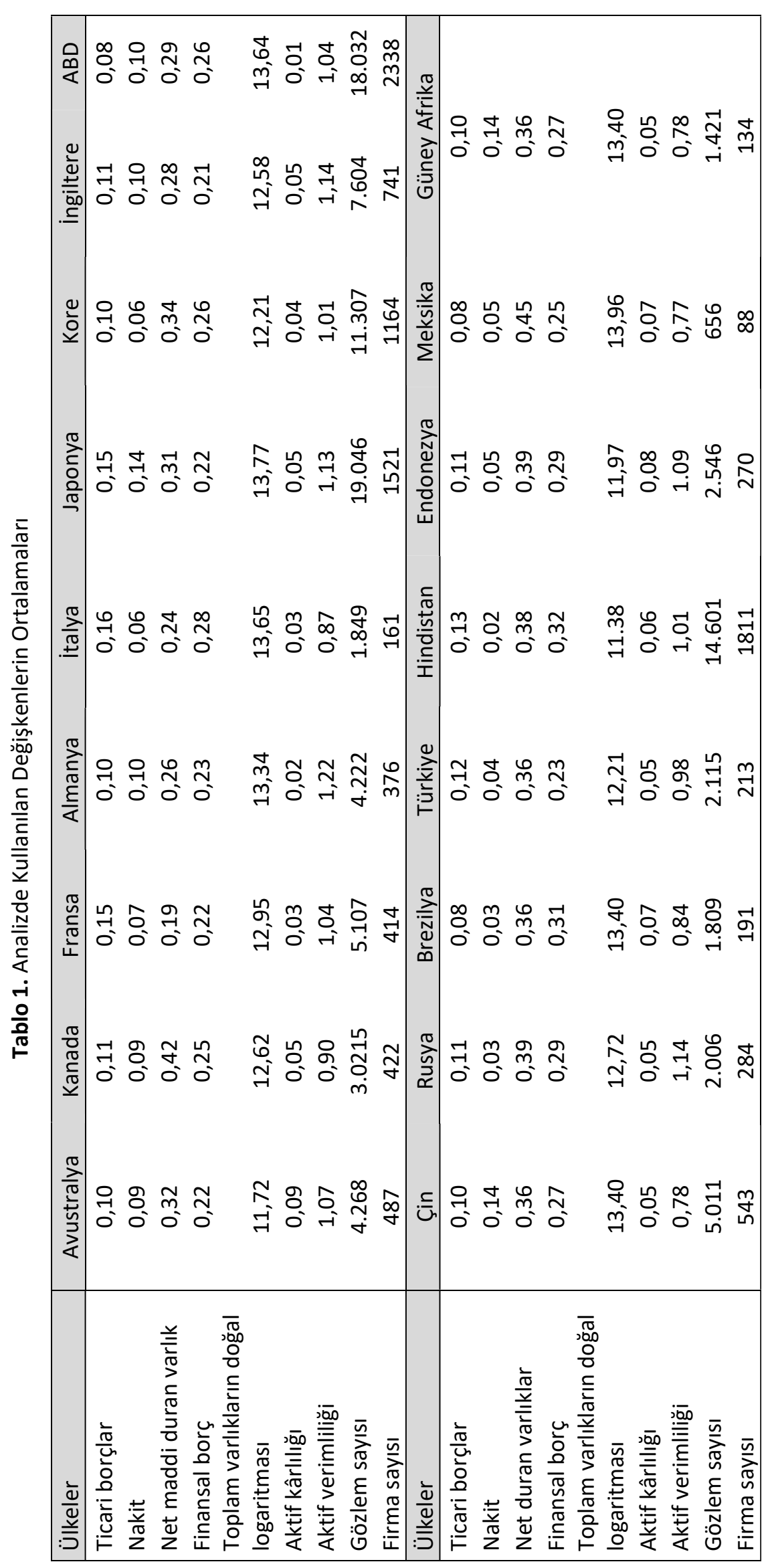


ikinci aşamada mevcut veriyi ve tahmin edilmeye çalışılan ekonomik ilişkiyi ortaya çıkaracak uygun OLS yönteminin (sabit firma etkisi veya rassal firma etkisinin) belirlenmesi amacıyla Hausman testi uygulanmıştır. Rassal etki modeli katsayılar için hesaplanacak standart hataları minimize etmesi bakımından etkin bir yöntemdir. Ancak gözlemlenemeyen ve zaman içerisinde değişmeyen firmalara özel niteliklerin analize dahil edilmemesi durumunda modelin kalıntıları ve açıklayıcı değişkenler arasındaki korelasyon tahmin edilen katsayılarda yanılılığa yol açacağı için bulunacak ilişki yanıltıcı olacaktır. Rassal etki modelinin yaratabileceği yanlılık Hausman testi ile test edilerek elde edilecek sonuca göre uygun model seçilmelidir (Brooks, 2014: 537-546). Bu amaçla her iki veri setine önce sabit etki daha sonra da rassal etki panel veri analizi yapılmış ve elde edilen katsayıları kıyaslayan Hausman testi uygulanmıştır (sonuçlar için bkz Ek.2). Test sonuçları rassal etki modelinin varsayımlarının ihlal edildiğini dolayısıyla da sabit etki modelinin uygun olduğunu ortaya koymuştur.

Analiz sonucu ortaya çıkan kalıntılarda değişen varyans olmaması ve kalıntıların gecikmeli değerleriyle kendi aralarında korelasyon bulunmaması OLS yönteminin temel varsayımlarındadır. Bu nedenle standart hataların robust yöntem kullanılmak suretiyle düzeltilerek hesaplanması sağlanmıştır. Bahsedilen yöntem katsayıların standart hatalarını değişen varyans ve otokorelasyona karşı düzelterek hesaplamaktadır (Stata 16 Temel Referans Kitabı, 2019: 455-456). Bu nedenle kalıntılara ayrıca test uygulanmamıştır6.

Verilerin analize hazır hale getirilmesi aşamasında uç değerler ile ilgili olarak şu düzenlemeler yapılmıştır. Toplam varlıklara oranlandıktan sonra $1^{\prime}$ den büyük ve $0^{\prime}$ dan küçük gözlemler ${ }^{7}$, negatif varlıklar, negatif satışlar elenmiştir. Kullanılan veriler ve ülkelere göre ortalamalar Tablo 1'de sunulmuştur. En çok TK kullanan firmalar İtalya, Fransa ve Japonya'da iken en az kredi kullanan firmalar ABD, Meksika ve Brezilya'da faaliyet göstermektedir. Ülke bazında TK kullanım oranları ise toplam varlıkların $\% 1^{\prime} i$ ve $\% 65^{\prime} i$ arasında değişmektedir.

Bu dalgalanmanın firmaların faaliyet gösterdiği endüstriden (bkz. Petersen ve Rajan, 1997) rekabet gücündeki farklılıklardan (bkz. Fabbri ve Klapper, 2016) ve banka kredisine erişim olanaklarından (bkz. Atanasova ve Wilson, 2003) kaynaklandığı tahmin edilmektedir. Finansal borç açısından bakıldığında da ortalama rakamlar birbirlerine çok yakındır. Gruplar arasındaki en önemli farklılık nakit seviyesinde göze çarpmaktadır. Ortalama nakit seviyesi gelişmekte olan ülkelerde $\% 5$ civarında iken, aynı oran gelişmiş ülkelerde \%10 civarındadır. Bu farklılı̆ın firmaların TK politikalarına da yansıması beklenmektedir. Ekonometrik analiz mevcut literatürdeki bazı çalışmalarda (örneğin; Petersen ve Rajan, 1997; GarciaAppendini ve Montoriol-Garriga, 2011; Abdulla vd., 2017) kullanılan ve firmaların TK politikaları üzerinde belirleyici rol oynadığı ortaya konan açıklayıcı değişkenler kullanılarak gerçekleştirilmiştir.

$$
\begin{aligned}
& T K_{i j t}^{D}=\alpha_{i}+\beta_{n} X_{i j t}+\varepsilon_{i t} \\
& \operatorname{lnBDH_{ijt}}=\alpha_{i}+\beta_{n} X_{i j t}+\varepsilon_{i t}
\end{aligned}
$$

Denklem 1'de verilen $T C_{i j t}^{D}$ firmaların ticari borçlarını ve Denklem 2'deki $\ln B D H_{i j t}$ ticari borçların devir hızının doğal logaritması, $X_{i j t}$ ise açıklayıcı değişkenlerini göstermektedir. Bu değişkenlerle ilgili detaylı bilgi Tablo 2'de yer almaktadır. Daha öncede bahsedildiği üzere bu çalışmanın hedefi 2008 finansal krizi ve ekonomik daralma dönemlerinde TK kullanımındaki değişiklikleri ortaya koymaktır. Dolayısıyla 2008 krizini ve daralma dönemlerini temsilen kukla değişkenler;

$D_{K r i z}:$ 2008-2009 ve 2010 yılları için 1, diğer yıllar için 0;

$D_{\text {yavaş }}$ : 2000-2014 yılları arasında, her ülkenin GSMH'sindeki en küçük büyümenin gerçekleştiği üç yıl için 1, diğer yıllar için 0 olacak şekilde oluşturulmuştur.

Literatürdeki bazı çalışmalar (örneğin; Deloof ve Jegers, 1996; Garcia-Appendini ve Montroel-Garriga, 2011), kısa vadeli likiditenin TK yönetimi açısından oldukça önemli olduğunu göstermektedir. Dolayısıyla firmaların ekonomik daralma dönemlerinde ellerindeki mevcut nakit stoğunun TK politikalarında belirleyici bir etken olabileceği ihtimali üzerine, likidite seviyesinin göstergesi olarak nakit seviyesi düşük firmaların 
reaksiyonları mercek altına alınmıştır. Gelişmiş ülkelerde $\% 10^{8}$ ve gelişen ülkelerde ise $\% 5^{\prime}$ in altında nakit stoğu bulunan firmalar için kukla değişken oluşturulmuş ve nakit oranı ile çarpılarak işleme sokulmuştur.

Benzer şekilde firmaların ticari borç seviyeleri üzerinde belirleyici rol oynayan bir diğer etken ise firmaların toplam varlıklarının büyüklüğüdür. Bazı çalışmalar (örneğin; Ng vd., 1999; Nilsen, 2002; Petersen ve Rajan, 1997), TK'lerin küçük firmalar için önemini vurgulamış ve bu tür firmalar için TK'lerin alternatif bir finansman aracı olduğunu dile getirmişlerdir. Bu hususun araştırılması, özellikle ekonomik daralma dönemlerinde küçük sayılabilecek firmaların davranışlarının ortaya koyulması bu çalışmanın amacı ve kapsamı açısından gereklidir. Bu nedenle, her iki grupta toplam varlıkları ortalamanın altında kalan firmalar kukla değişken atanarak analize dâhil edilmişlerdir.

Likid_Kit $=\frac{\text { nakit }_{\text {ijt }}}{\text { Varlıklar }_{i j t}} * D_{\text {likid }} ; D_{\text {nakit }}=1$ ĕger $\frac{\text { nakit }_{i j t}}{\text { DönenVarlıklar }_{i j t}}<0.10$ aksi halde $D_{\text {likid }}=0$.

Küçük_firma $=\log \left(\right.$ Varlıklar $\left._{i j t}\right) * D_{\text {küçük }} ; \quad D_{\text {küçük }}=1$ eğer Varlıklar $_{i j t}<$ ortalama Varlıklar aksi halde $D_{k \text { üçük }}=0$.

Küçük_likid_kıt $=\frac{\text { nakit }_{i j t}}{\text { Varlıklar }_{i j t}} * D_{\text {küçük }} * D_{\text {nakit }}$ değişkeni ise nakit stoğu düşük küçük firmaların davranışlarının incelenebilmesi açısından oluşturulmuştur.

Bir sonraki aşamada küçük firma olmanın ve düşük likidite seviyesinin kriz dönemlerindeki etkisi araştırılmış bu amaçla da;

$$
\begin{aligned}
& \operatorname{Kriz}_{\text {küçük }}{ }_{f i r m a}=D_{\text {Kriz }} * \text { Küçü } k_{-} \text {firma, } \\
& \text { Kriz }_{\text {likid }}{ }_{\text {klt }}=D_{\text {Kriz }}{ }^{*} \text { Likid_klt , } \\
& \operatorname{Kriz}_{k \text { üçük } \text { Likid }_{k l t}}=D_{\text {Kriz }}{ }^{*} D_{k \text { üçük }} * \text { Likid_klt }
\end{aligned}
$$

değişkenleri oluşturulmuştur. Bu sayede kriz dönemlerinde küçük firma ve likidite azlığının etkisi ayrıştırılabilecektir. Daralma dönemleri için de benzer şekilde;

$$
\begin{aligned}
& \text { Yavaş }_{\text {küçük }} \text { firma }=D_{\text {yavaş }}{ }^{*} \text { Küçük_firma } \\
& \text { YavașLikid }_{\text {klt }}=D_{\text {yavaș }}{ }^{*} \text { Likid_kut, } \\
& \text { Yavaş }_{k u ̈ c ̧ u ̈ k_{L i k i d}}=D_{\text {yavaş }}{ }^{*} D_{\text {küçük }} * \text { Likid_klt }
\end{aligned}
$$

\begin{tabular}{|c|c|c|}
\hline \multicolumn{3}{|c|}{ Bağımlı Değişkenler } \\
\hline$T K_{i j t}^{D}$ & $\begin{array}{l}\text { Ticari Borçlar ( } 320+420 \text { nolu hesapların } \\
\text { bakiyelerinin toplamı) }\end{array}$ & Ticari Borçlar $_{i j t} /$ Varlıklar $_{i j t}$ \\
\hline $\operatorname{InBDH}$ & Ticari borçların devir hızının logaritması & $\ln \left(\right.$ SatışlarınMaliyeti $_{i j t}$ /TicariBorçlar $\left._{i j t}\right)$ \\
\hline \multicolumn{3}{|c|}{ Açıklayıcı Değişkenler } \\
\hline Nakit & Kasadaki nakit mevcudu & Nakit $_{i j t} /$ Varlıklar $_{i j t}$ \\
\hline Maddi & & M. DuranVarllklar ${ }_{i j t} /$ Varllklar $_{i j t}$ \\
\hline Duran & Net maddi duran varlıklar & \\
\hline Kârlılık & Aktiflerin kârlılığı & FaaliyetKarl $_{i j t} /$ Varllklar $_{i j t}$ \\
\hline Borç & Banka kredileri ve faiz yükleyen diğer borçlar & FinansalBorçlar $_{i j t} /$ Varllklar $_{i j t}$ \\
\hline Hacim & Toplam varlıkların logaritması & $\ln (\text { Varlıklar })_{i j t}$ \\
\hline Verimlilik & Satışların varlıklara oranı & Satışlar $_{i j t} /$ Varlıklar $_{i j t}$ \\
\hline
\end{tabular}

değişkenleri oluşturulmuş, bu sayede daralma dönemlerinde sırasıyla küçük firmaların, düşük likiditenin ve düşük likiditeli küçük firmaların TK politikalarındaki değişimin tespiti amaçlanmıştır.

Tablo 2. Regresyonda Kullanılan Değişkenler ve Tanımları 


\section{Ampirik Bulgular}

\subsection{Ticari Borçların Tutarı}

Tablo 3 gelişmiş ülkelerde faaliyet gösteren halka açık firmaların verisi ile elde edilmiş analiz sonuçlarını ve parantez içerisinde ilişkin robust standart hataları rapor etmektedir. Birinci sütunda Denklem 1'deki veriler sabit etki panel veri analizi yöntemiyle çalışılmış ve sonuçlar TK'lerin nakit stoğu, sabit varlıklar, banka kredileri, firma büyüklüğü gibi değişkenlerden olumsuz etkilendiğini göstermiştir. Literatürdeki mevcut çalışmalar firmaların özellikle dışarıdan kaynak temin etme sürecinde büyüklüklerinin doğrudan etkili olabileceğini dile getirmektedir. Örneğin, Beck vd. (2005) toplam varlık hacminin krediye erişimde önemli bir etken olduğunu göstermiştir. Burada da benzer olarak büyüklük (varlıklar), finansal borç, nakit stoğu ve duran varlıkların TK kullanımına olan negatif etkileri Tablo 3'ün 1. sütunundaki negatif ve anlamlı katsayılardan görülmektedir. Diğer taraftan verimlilik katsayısı TK kullanımına olumlu etki yapmaktadır. Yine Tablo 3'ün 2. sütununda hem küçük hem de düşük nakit stoklu firmaların TK kullanımındaki hassasiyetleri öne çıkmaktadır.Küçük firma değişkeni katsayısı negatif ve istatistiksel olarak anlamlıdır, bu da beklentinin aksine daha az TK kullandıklarını ifade etmektedir. Bunun farklı nedenleri olabileceği gibi literatürdeki çalışmaların sonuçları TK'lerin maliyetine işaret etmektedir, zira pek çok çalışma (Petersen ve Rajan, 1997; Ng vd., 1999; Danielson ve Scott, 2004; Cuñat, 2007) TK'lerin geleneksel banka kredisinden çok daha maliyetli olduğunu öne sürmektedir. Yine Tablo 3'ün 2. sütununda düşük nakit stoğunun TK talebini olumlu etkilediği görülmektedir. Benzer olarak 3. sütunda düşük likiditeli küçük firmaların durumu incelenmiş ve bu firmaların da TK talebinin diğer firmalara nazaran fazla olduğu gözlenmiştir. Küçük firmaların TK kullanımının diğer firmalara oranla düşük olmasına rağmen likidite daralması söz konusu olduğunda TK talebini arttırmaları likidite seviyesinin tedarikçi finansmanına olan talepte ne derece etkili olduğunu vurgulamaktadır.

Tablo 3. Küçüklük ve Likidite Etkisi (Gelişmiş Ülkeler)

\begin{tabular}{|c|c|c|c|c|c|c|c|}
\hline \multicolumn{8}{|c|}{ Bağımlı Değişken: Ticari Kredi Miktarı } \\
\hline & 1 & 2 & 3 & 4 & 5 & 6 & 7 \\
\hline Nakit & $\begin{array}{c}-0,048^{* * *} \\
(0,004)\end{array}$ & $\begin{array}{c}-0,043^{* * *} \\
(0,004)\end{array}$ & $\begin{array}{c}-0,043 * * * \\
(0,004)\end{array}$ & $\begin{array}{c}-0,043^{* * *} \\
(0,004)\end{array}$ & $\begin{array}{c}-0,048^{* * *} \\
(0,004)\end{array}$ & $\begin{array}{c}-0,048^{* * *} \\
(0,004)\end{array}$ & $\begin{array}{c}-0,048^{* * *} \\
(0,004)\end{array}$ \\
\hline Maddi duran & $\begin{array}{c}-0,043 * * * \\
(0,004)\end{array}$ & $\begin{array}{c}-0,042^{* * *} \\
(0,004)\end{array}$ & $\begin{array}{c}-0,043 * * * \\
(0,004)\end{array}$ & $\begin{array}{c}-0,042^{* * *} \\
(0,004)\end{array}$ & $\begin{array}{c}-0,044 * * * \\
(0,004)\end{array}$ & $\begin{array}{c}-0,044^{* * *} \\
(0,004)\end{array}$ & $\begin{array}{c}-0,044^{* * *} \\
(0,004)\end{array}$ \\
\hline Borç & $\begin{array}{c}-0,011 * * * \\
(0,003)\end{array}$ & $\begin{array}{c}-0,011^{* * *} \\
(0,003)\end{array}$ & $\begin{array}{c}-0,011 * * * \\
(0,003)\end{array}$ & $\begin{array}{c}-0,010^{* * *} \\
(0,003)\end{array}$ & $\begin{array}{c}-0,011^{* * *} \\
(0,003)\end{array}$ & $\begin{array}{c}-0,011^{* * *} \\
(0,003)\end{array}$ & $\begin{array}{c}-0,011^{* * *} \\
(0,003)\end{array}$ \\
\hline Hacim & $\begin{array}{c}-0,007 * * * \\
(0,001)\end{array}$ & $\begin{array}{c}-0,007^{* * *} \\
(0,001)\end{array}$ & $\begin{array}{c}-0,006^{* * *} \\
(0,001)\end{array}$ & $\begin{array}{c}-0,007^{* * *} \\
(0,001)\end{array}$ & $\begin{array}{c}-0,007^{* * *} \\
(0,001)\end{array}$ & $\begin{array}{c}-0,007^{* * *} \\
(0,001)\end{array}$ & $\begin{array}{c}-0,007 * * * \\
(0,001)\end{array}$ \\
\hline Kârlılık & $\begin{array}{c}-0,054^{* * *} \\
(0,005)\end{array}$ & $\begin{array}{c}-0,054^{* * *} \\
(0,005)\end{array}$ & $\begin{array}{c}-0,054 * * * \\
(0,005)\end{array}$ & $\begin{array}{c}-0,054^{* * *} \\
(0,005)\end{array}$ & $\begin{array}{c}-0,054^{* * *} \\
(0,005)\end{array}$ & $\begin{array}{c}-0,054^{* * *} \\
(0,005)\end{array}$ & $\begin{array}{c}-0,054^{* * *} \\
(0,005)\end{array}$ \\
\hline Verimlilik & $\begin{array}{c}0,056^{* * *} \\
(0,003)\end{array}$ & $\begin{array}{c}0,056^{* * *} \\
(0,003)\end{array}$ & $\begin{array}{c}0,056^{* * *} \\
(0,003)\end{array}$ & $\begin{array}{c}0,056 * * * \\
(0,003)\end{array}$ & $\begin{array}{c}0,056^{* * *} \\
(0,003)\end{array}$ & $\begin{array}{c}0,056^{* * *} \\
(0,003)\end{array}$ & $\begin{array}{c}0,056^{* * *} \\
(0,003)\end{array}$ \\
\hline Likid_kıt & & $\begin{array}{c}0,108 * * * \\
(0,019)\end{array}$ & & $\begin{array}{c}0,108 * * * \\
(0,019)\end{array}$ & & & \\
\hline Küçük_firma & & $\begin{array}{c}-0,002^{* * *} \\
(0,000)\end{array}$ & & $\begin{array}{c}-0,002^{* * *} \\
(0,000)\end{array}$ & & & \\
\hline Küçük_likid_kıt & & & $\begin{array}{c}0,154^{* * *} \\
(0,026)\end{array}$ & & & & \\
\hline Kriz & & & & $\begin{array}{c}-0,008^{* * *} \\
(0,001)\end{array}$ & $\begin{array}{c}-0,009 * * * \\
(0,001)\end{array}$ & $\begin{array}{c}-0,008^{* * *} \\
(0,001)\end{array}$ & $\begin{array}{c}-0,008^{* * *} \\
(0,001)\end{array}$ \\
\hline Kriz_likid_kit & & & & & $\begin{array}{c}0,079 * * * \\
(0,005)\end{array}$ & & \\
\hline Kriz_küçük_firma & & & & & & $\begin{array}{l}-0,0001 \\
(0,001)\end{array}$ & \\
\hline Kriz_küçük_likid_kıt & & & & & & & $\begin{array}{c}0,087^{* *} \\
(0,041\end{array}$ \\
\hline Yıl kukla & Evet & Evet & Evet & Evet & Evet & Evet & Evet \\
\hline Sabit & Evet & Evet & Evet & Evet & Evet & Evet & Evet \\
\hline $\mathrm{R}^{2}$ & 0,201 & 0,203 & 0,202 & 0,203 & 0,201 & 0,201 & 0,201 \\
\hline Prob $>\mathrm{F}$ & 0,000 & 0,000 & 0,000 & 0,000 & 0,000 & 0,000 & 0,000 \\
\hline
\end{tabular}


Tablo 3'teki 4, 5, 6 ve 7. sütunlar 2008 krizinin ve kriz döneminde firma küçüklüğünün ve likiditenin TK talebinde nasıl bir rol oynadığını ortaya çıkarmayı hedeflemektedir. Genel olarak ekonomik aktivitede meydana gelen yavaşlama firmaları olumsuz etkilemekte ve kaynak bulmakta zorlanan firmaları alternatif kaynak arayışlarına itmektedir (Atanasova ve Wilson, 2003). Tablo 3'te 4. sütunda kriz kukla değişkeninin katsayısı negatif ve anlamlıdır; krizle birlikte TK kullanımı belirgin şekilde azalmıştır. Bu azalışın farklı nedenleri olabileceği gibi, krizin genel likidite üzerinde yarattığı baskıyla genel TK miktarının düşmüş olabileceği, satış hacmindeki azalışın TK kullanımını azaltmış olması ihtimali ve o dönemde izlenen aşırı genişlemeci para politikalarının firmaların kısa vadeli kaynak ihtiyaçlarını karşılamasından ötürü TK'ye olan talebin düşmüş olması muhtemel sebepler arasında değerlendirilmektedir.

Tablo 4. Küçüklük ve Likidite Etkisi (Gelişen Ülkeler)

\begin{tabular}{|c|c|c|c|c|c|c|c|}
\hline \multicolumn{8}{|c|}{ Bağımlı Değişken: Ticari Kredi Miktarı } \\
\hline & 1 & 2 & 3 & 4 & 5 & 6 & 7 \\
\hline Nakit & $\begin{array}{c}-0,045^{* * *} \\
(0,009)\end{array}$ & $\begin{array}{c}-0,044^{* * *} \\
(0,009)\end{array}$ & $\begin{array}{c}-0,041^{* * *} \\
(0,009)\end{array}$ & $\begin{array}{c}-0,044^{* * *} \\
(0,009)\end{array}$ & $\begin{array}{c}-0,044^{* * *} \\
(0,009)\end{array}$ & $\begin{array}{c}-0,044^{* * *} \\
(0,009)\end{array}$ & $\begin{array}{c}-0,043^{* * *} \\
(0,009)\end{array}$ \\
\hline Maddi duran & $\begin{array}{c}-0,039 * * * \\
(0,005)\end{array}$ & $\begin{array}{c}-0,039 * * * \\
(0,005)\end{array}$ & $\begin{array}{c}-0,038^{* * *} \\
(0,005)\end{array}$ & $\begin{array}{c}-0,039 * * * \\
(0,005)\end{array}$ & $\begin{array}{c}-0,039 * * * \\
(0,005)\end{array}$ & $\begin{array}{c}-0,039 * * * \\
(0,005)\end{array}$ & $\begin{array}{c}-0,039 * * * \\
(0,005)\end{array}$ \\
\hline Borç & $\begin{array}{c}-0,042^{* * *} \\
(0,005)\end{array}$ & $\begin{array}{c}-0,042^{* * *} \\
(0,005)\end{array}$ & $\begin{array}{c}-0,042^{* * *} \\
(0,005)\end{array}$ & $\begin{array}{c}-0,042^{* * *} \\
(0,005)\end{array}$ & $\begin{array}{c}-0,042^{* * *} \\
(0,005)\end{array}$ & $\begin{array}{c}-0,042^{* * *} \\
(0,005)\end{array}$ & $\begin{array}{c}-0,042^{* * *} \\
(0,005)\end{array}$ \\
\hline Hacim & $\begin{array}{c}-0.002 \\
(0,001)\end{array}$ & $\begin{array}{c}-0.001 \\
(0,001)\end{array}$ & $\begin{array}{c}-0.002 \\
(0,001)\end{array}$ & $\begin{array}{c}-0.002 \\
(0,001)\end{array}$ & $\begin{array}{c}-0.002 \\
(0,001)\end{array}$ & $\begin{array}{c}-0.002 \\
(0,001)\end{array}$ & $\begin{array}{c}-0.002 \\
(0,001)\end{array}$ \\
\hline Kârlılık & $\begin{array}{c}-0,068 * * * \\
(0,008)\end{array}$ & $\begin{array}{c}-0,0698^{* * *} \\
(0,008)\end{array}$ & $\begin{array}{c}-0,068^{* * *} \\
(0,008)\end{array}$ & $\begin{array}{c}-0,068^{* * *} \\
(0,008)\end{array}$ & $\begin{array}{c}-0,068^{* * *} \\
(0,008)\end{array}$ & $\begin{array}{c}-0,068^{* * *} \\
(0,008)\end{array}$ & $\begin{array}{c}-0,068 * * * \\
(0,008)\end{array}$ \\
\hline Verimlilik & $\begin{array}{c}0,038^{* * *} \\
(0,003)\end{array}$ & $\begin{array}{c}0,038^{* * *} \\
(0,003)\end{array}$ & $\begin{array}{c}0,038 * * * \\
(0,003)\end{array}$ & $\begin{array}{c}0,038 * * * \\
(0,003)\end{array}$ & $\begin{array}{c}0,038 * * * \\
(0,003)\end{array}$ & $\begin{array}{c}0,038^{* * *} \\
(0,003)\end{array}$ & $\begin{array}{c}0,038^{* * *} \\
(0,003)\end{array}$ \\
\hline \multicolumn{2}{|l|}{ Likid_kıt } & $\begin{array}{c}0,151^{* *} \\
(0,061)\end{array}$ & & & & & \\
\hline \multicolumn{2}{|l|}{ Küçük_firma } & $\begin{array}{c}0,001^{* * *} \\
(0,001)\end{array}$ & & & & & \\
\hline \multicolumn{2}{|l|}{ Küçük_likid_kıt } & & $\begin{array}{c}0,090 \\
(0,093)\end{array}$ & & & & \\
\hline \multicolumn{2}{|l|}{ Yavaş } & & & $\begin{array}{c}0,004^{* * *} \\
(0,001)\end{array}$ & $\begin{array}{c}0,004^{* * *} \\
(0,001)\end{array}$ & $\begin{array}{c}0,004 * * * \\
(0,001)\end{array}$ & $\begin{array}{c}0,004^{* * *} \\
(0,001)\end{array}$ \\
\hline \multicolumn{2}{|c|}{ Yavaş_küçük_firma } & & & & $\begin{array}{l}0,0001 \\
(0,001)\end{array}$ & & \\
\hline \multicolumn{2}{|l|}{ Yavaş_likid_kıt } & & & & & $\begin{array}{l}-0,086 \\
(0,115)\end{array}$ & \\
\hline \multicolumn{3}{|c|}{ Yavaş_küçük_likid_kıt } & & & & & $\begin{array}{c}0,103 \\
(0,116)\end{array}$ \\
\hline Yıl kukla & Evet & Evet & Evet & Evet & Evet & Evet & Evet \\
\hline Sabit & Evet & Evet & Evet & Evet & Evet & Evet & Evet \\
\hline $\mathrm{R}^{2}$ & 0,08 & 0,08 & 0,08 & 0,08 & 0,08 & 0,08 & 0,08 \\
\hline Prob > F & 0,000 & 0,000 & 0,000 & 0,000 & 0,000 & 0,000 & 0,000 \\
\hline
\end{tabular}

Nitekim Tablo 3'te 5. ve 7. Sütundaki sonuçlar düşük likiditeli firmaların bu dönemde TK kullanımını arttırdığını doğrulamaktadır. Buna karşın küçük firma değişkeni istatistiksel olarak anlamlı değildir ve ilişkinin yönü negatif olarak bulunmuştur. İncelenen dönemde gelişmekte olan ülkelerin tamamını etkileyen 2008 krizine benzer global seviyede bir kriz olmadığı için gelişen ülke verileri sadece ekonomik küçülme dönemleri üzerinden incelenmiştir. Ekonomik daralma dönemleri GSMH'deki düşüş dikkate alındığında ekonomik krizlere benzer özellikler gösterebilir. Örneğin firmaların satış gelirlerinde azalma, teminat değerlerindeki düşüş ve bunların yabancı kaynağa erişimde oynayacağı rol (bkz. Bernanke vd. 1996) kriz dönemleriyle benzerdir. Bu nedenle her ülkenin GSMH'sindeki en küçük büyümenin gerçekleştiği üç yıl mercek altına alınmıştır. Esasında bu dönemde gerçekleşen büyüme rakamlarının yarısı negatif olması itibariyle zaten ekonomik bir kriz atmosferindedir. Genel olarak 2000'li yılların başları, 2009 yılı ve incelenen dönemin son yılları bu rakamların gerçekleştiği yıllar olarak karşımıza çıkmaktadır. Analiz sonuçları ve ilişkin robust standart 
hatalar parantez içerisinde Tablo 4'te raporlanmıştır Nitekim elde edilen bazı sonuçlar, örneğin firma bazlı değişkenler önceki bulguları teyit ederken, daralma, likidite ve küçük firma değişkenleri önceki sonuçlar ile çelişmektedir. Temel analizde kontrol değişkenleri benzer etkileri gösterse de analizin devamında iki grup arasında önemli farklılıklar gözlenmiştir. Örneğin Tablo 4'ün 2. sütununda hem küçük firma hem de düşük likidite değişkeni pozitif ve anlamlıdır. Dolayısıyla normal zamanlarda küçük veya likidite sıkıntısı yaşayan firmalar diğer firmalara nazaran daha fazla tedarikçi finansmanı kullanmaktadırlar, hâlbuki gelişmiş ülkelerde küçük firmalar diğer firmalara nazaran daha az kredi kullanmaktadırlar.

Sıkıntılı dönemlerde ise, gelişmiş ülke firmalarının aksine, TK kullanımı tüm firmalarda artmaktadır. Yine bu dönemlerde krediye erişimin güçleşmesi, satışlardaki azalma ve mevcut envanterin nakde çevrilmesindeki gecikmelerin TK kullanımını arttırdığı değerlendirilmektedir. Diğer taraftan gelişmiş ülkelerde olduğu gibi, daralma dönemlerinde küçük ve/veya düşük likiditeli firmalar açısından anlamlı bir sonuç yakalanamamıştır. Tablo 3 ve 4 'te sunulan veriler birlikte değerlendirildiğinde, ekonominin sıkıntıda olduğu dönemlerde gelişen ve gelişmiş ülke firmalarının TK politikalarının örtüşmediğini ancak nakit sıkıntısı içerisinde olan firmaların normal ve sıkıntılı dönemlerde benzer reaksiyon gösterdiğini telaffuz etmek yerinde olacaktır.

Tablo 5. Küçüklük ve Likidite Etkisi (Gelişmiş Ülkeler)

\begin{tabular}{|c|c|c|c|c|c|}
\hline \multicolumn{6}{|c|}{ Bağımlı Değişken: Ticari Kredi Miktarı } \\
\hline & 1 & 2 & 3 & 4 & 5 \\
\hline Nakit & $\begin{array}{c}-0,048 * * * \\
(0,004)\end{array}$ & $\begin{array}{c}-0,048^{* * *} \\
(0,004)\end{array}$ & $\begin{array}{c}-0,048 * * * \\
(0,004)\end{array}$ & $\begin{array}{c}-0,048 * * * \\
(0,004)\end{array}$ & $\begin{array}{c}-0,048 * * * \\
(0,004)\end{array}$ \\
\hline Maddi duran & $\begin{array}{c}-0,044^{* * *} \\
(0,004)\end{array}$ & $\begin{array}{c}-0,043 * * * \\
(0,004)\end{array}$ & $\begin{array}{c}-0,043^{* * *} \\
(0,004)\end{array}$ & $\begin{array}{c}-0,043^{* * *} \\
(0,004)\end{array}$ & $\begin{array}{c}-0,044^{* * *} \\
(0,004)\end{array}$ \\
\hline Borç & $\begin{array}{c}-0,011^{* * *} \\
(0,003)\end{array}$ & $\begin{array}{c}-0,011^{* * *} \\
(0,003)\end{array}$ & $\begin{array}{c}-0,011^{* * *} \\
(0,003)\end{array}$ & $\begin{array}{c}-0,011^{* * *} \\
(0,003)\end{array}$ & $\begin{array}{c}-0,011^{* * *} \\
(0,003)\end{array}$ \\
\hline Hacim & $\begin{array}{c}-0,007^{* * *} \\
(0,002)\end{array}$ & $\begin{array}{c}-0,007^{* * *} \\
(0,001)\end{array}$ & $\begin{array}{c}-0,007^{* * *} \\
(0,001)\end{array}$ & $\begin{array}{c}-0,007 * * * \\
(0,001)\end{array}$ & $\begin{array}{c}-0,007 * * * \\
(0,001)\end{array}$ \\
\hline Kârlılık & $\begin{array}{c}-0,055^{* * *} \\
(0,005)\end{array}$ & $\begin{array}{c}-0,055^{* * *} \\
(0,005)\end{array}$ & $\begin{array}{c}-0,055^{* * *} \\
(0,005)\end{array}$ & $\begin{array}{c}-0,055^{* * *} \\
(0,005)\end{array}$ & $\begin{array}{c}-0,055^{* * *} \\
(0,005)\end{array}$ \\
\hline Verimlilik & $\begin{array}{c}0,056 * * * \\
(0,003)\end{array}$ & $\begin{array}{c}0,056^{* * *} \\
(0,003)\end{array}$ & $\begin{array}{c}0,056^{* * *} \\
(0,003)\end{array}$ & $\begin{array}{c}0,056^{* * *} \\
(0,003)\end{array}$ & $\begin{array}{c}0,056^{* * *} \\
(0,003)\end{array}$ \\
\hline Yavaş & $\begin{array}{c}-0,004^{* * *} \\
(0,001)\end{array}$ & $\begin{array}{c}-0,004^{* * *} \\
(0,001)\end{array}$ & $\begin{array}{c}-0,005^{* * *} \\
(0,001)\end{array}$ & $\begin{array}{c}-0,004^{* * *} \\
(0,001)\end{array}$ & $\begin{array}{c}-0,005^{* * *} \\
(0,001)\end{array}$ \\
\hline Yavaş_küçük_firma & & $\begin{array}{l}-0,004 \\
(0,004)\end{array}$ & & $\begin{array}{l}-0,001 \\
(0,001)\end{array}$ & \\
\hline Yavaş_likid_kıt & & & $\begin{array}{c}0,073^{* * *} \\
(0,026)\end{array}$ & $\begin{array}{c}0,074 * * * \\
(0,026)\end{array}$ & \\
\hline Yavaş_küçük_likid_kıt & & & & & $\begin{array}{c}0,103^{* * *} \\
(.0,038)\end{array}$ \\
\hline Yıl kukla & Evet & Evet & Evet & Evet & Evet \\
\hline Sabit & Evet & Evet & Evet & Evet & Evet \\
\hline $\mathrm{R}^{2}$ & 0,202 & 0,201 & 0,202 & 0,202 & 0,202 \\
\hline Prob $>\mathrm{F}$ & 0,000 & 0,000 & 0,000 & 0,000 & 0,000 \\
\hline
\end{tabular}

Gelişmiş ülkelerin TK miktarlarındaki değişim, GSMH'deki en küçük büyümenin gerçekleştiği dönemlerde de incelenmiştir. Bu uygulamanın amacı bahsedilen farklılık/benzerliklerin sağlamlığını (robustness) ve benzer dönemlerde aynı sonuçların elde edilip dilemeyeceğini test etmektir. Bulgular ve ilişkin robust standart hatalar parantez içerisinde Tablo 5'te verilmiştir. Ekonomik küçülme kuklası negatif ve anlamlı bir katsayıya sahiptir, bu da bu dönemlerde alınan TK'lerde düşüş olduğunu göstermektedir. Nitekim aynı etki 2008 krizi döneminde de ortaya çıkmaktadır ki bunun hem kriz dönemlerinde hem de daralma dönemlerinde ortaya çıkmış olması, satışlardaki azalmanın ve genel likiditedeki daralmanın bir sonucu olduğu tezini desteklemektedir. Gelişmekte olan ülkelerde ise hatırlanacağı gibi tam tersi daralma dönemleri etkisi pozitiftir, yani bu dönemlerde ortalama olarak TK talebi artmaktadır. Küçük firma değişkeni anlamlı bir etki 
meydana getirmez iken, düşük likiditeli firmalar ve düşük likiditeli küçük firmalar bu dönemlerde daha çok TK talep etmektedirler. Dolayısıyla bu sonuçlar da 2008 krizinin yarattığı etkilerle benzerdir. Her iki dönemde de düşük likiditeli firmaların daha çok tedarikçi finansmanı kullandıkları yönünde güçlü kanıtlar mevcuttur.

\subsection{Ticari Borçların Vadesi}

Firmaların zor dönemlerde iş ortaklarına sunmuş oldukları TK'ler dayanışmanın bir göstergesidir ve sadece kredilerin miktarındaki artış ya da azalışlar değil kredi vadelerindeki değişimler de bize bu konuda bir dönüt verebilir. Zira ekonominin resesyona girdiği dönemlerin firma nezdinde en önemli yansımalarından bir tanesi satışlardaki azalmadır. Satışlarda düşüş olduğu için stok devir hızında bir yavaşlama ve beraberinde nakit akışında daralma kaçınıımazdır. Dolayısıyla TK vadelerinin de hem nakit akışındaki azalmadan hem de stok devir hızındaki yavaşlamadan etkilenmesi beklenir. Çalışmanın bu bölümü bahsedilen etkilerin ortaya çıkarılması, bunun yanında küçük firma ve düşük likiditenin bu denklemde nasıl bir etki yarattığını incelemeyi amaçlamaktadır. Tablo 6 gelişmiş ülke firmalarının TK vadelerindeki değişimin diğer kontrol değişkenlerinin yanı sıra kriz döneminden nasıl etkilendiğini raporlamaktadır, robust standart hatalar parantez içerisinde verilmiştir. Pozitif katsayılı değişkenler vadenin kısaldığını, yani borçların daha hızlı tahsil edildiğini ifade ederken, negatif katsayılar vadenin uzadığına işaret etmektedir. Sütun 1'de görüldüğü üzere nakit miktarı, duran varlıklar, finansal borçlar, toplam varlıkların hacmi ve diğer kârlıık değişkenleri vadeyi kısaltıcı etkiye sahiptir. Genel olarak firmanın likiditesini belirleyen değişkenler; örneğin kasa mevcudu, finansal krediler ve kârlıık, borç ödeyebilme kapasitesine doğrudan etki ettiği için, arttıkça kullanılan TK'nin vadesi de düşmektedir.

Tablo 6. Küçüklük ve Likidite Etkisi (Gelişmiş Ülkeler)

\begin{tabular}{|c|c|c|c|c|c|c|c|}
\hline \multicolumn{8}{|c|}{ Bağımlı Değişken: Ticari Kredi Kullanım Süresi } \\
\hline & 1 & 2 & 3 & 4 & 5 & 6 & 7 \\
\hline Nakit & $\begin{array}{c}0,261^{* * *} \\
(0,036)\end{array}$ & $\begin{array}{c}0,233 * * * \\
(0,037)\end{array}$ & $\begin{array}{c}0,208 * * * \\
(0,037)\end{array}$ & $\begin{array}{c}0,233^{* * *} \\
(0,037)\end{array}$ & $\begin{array}{c}0,256^{* * *} \\
(0,036)\end{array}$ & $\begin{array}{c}0,261^{* * *} \\
(0,036)\end{array}$ & $\begin{array}{c}0,249 * * * \\
(0,036)\end{array}$ \\
\hline Maddi Duran & $\begin{array}{c}0,159 * * * \\
(0,043)\end{array}$ & $\begin{array}{c}0,161 * * * \\
(0,043)\end{array}$ & $\begin{array}{c}0,163 * * * \\
(0,043)\end{array}$ & $\begin{array}{c}0,160 * * * \\
(0,043)\end{array}$ & $\begin{array}{c}0,167^{* * *} \\
(0,043)\end{array}$ & $\begin{array}{c}0,158^{* * *} \\
(0,043)\end{array}$ & $\begin{array}{c}0,167 * * * \\
(0,043)\end{array}$ \\
\hline Borç & $\begin{array}{c}0,053^{* *} \\
(0,027)\end{array}$ & $\begin{array}{c}0,053^{* *} \\
(0,027)\end{array}$ & $\begin{array}{c}0,055^{* *} \\
(0,027)\end{array}$ & $\begin{array}{c}0,054^{* *} \\
(0,027)\end{array}$ & $\begin{array}{c}0,055^{* *} \\
(0,027)\end{array}$ & $\begin{array}{c}0,054^{* *} \\
(0,027)\end{array}$ & $\begin{array}{c}0,056 * * \\
(0,027)\end{array}$ \\
\hline Hacim & $\begin{array}{c}0,033^{* * *} \\
(0,008)\end{array}$ & $\begin{array}{c}0,036 * * * \\
(0,008)\end{array}$ & $\begin{array}{c}0,032 * * * \\
(0,008)\end{array}$ & $\begin{array}{c}0,036^{* * *} \\
(0,008)\end{array}$ & $\begin{array}{c}0,034 * * * \\
(0,008)\end{array}$ & $\begin{array}{c}-0,033^{* * *} \\
(0,008)\end{array}$ & $\begin{array}{c}0,034^{* * *} \\
(0,008)\end{array}$ \\
\hline Kârlılık & $\begin{array}{c}0,033 \\
(0,027)\end{array}$ & $\begin{array}{c}0,032 \\
(0,027)\end{array}$ & $\begin{array}{c}0,034 \\
(0,027)\end{array}$ & $\begin{array}{c}0,032 \\
(0,027)\end{array}$ & $\begin{array}{c}0,033 \\
(0,027)\end{array}$ & $\begin{array}{c}0,034 \\
(0,027)\end{array}$ & $\begin{array}{c}0,034 \\
(0,027)\end{array}$ \\
\hline Verimlilik & $\begin{array}{l}.279 * * * \\
(0,018)\end{array}$ & $\begin{array}{c}0,281 * * * \\
(0,018)\end{array}$ & $\begin{array}{c}0,281 * * * \\
(0,018)\end{array}$ & $\begin{array}{c}0,280 * * * \\
(0,018)\end{array}$ & $\begin{array}{c}0,281^{* * *} \\
(0,018)\end{array}$ & $\begin{array}{c}0,279 * * * \\
(0,018)\end{array}$ & $\begin{array}{c}0,281 * * * \\
(0,018)\end{array}$ \\
\hline Likid_kıt & & $\begin{array}{c}-0,389 * * * \\
(0,135)\end{array}$ & & $\begin{array}{c}-0,388^{* * *} \\
(0,135)\end{array}$ & & & \\
\hline Küçük_firma & & $\begin{array}{l}0,0001 \\
(0,001)\end{array}$ & & $\begin{array}{l}0,0001 \\
(0,002)\end{array}$ & & & \\
\hline Küçük_likid_kıt & & & $\begin{array}{c}-0,599 * * * \\
(0,189)\end{array}$ & & & & \\
\hline Kriz & & & & $\begin{array}{c}0,095^{* * *} \\
(0,011)\end{array}$ & $\begin{array}{c}0,098 * * * \\
(0,011)\end{array}$ & $\begin{array}{c}0,099 * * * \\
(0,012)\end{array}$ & $\begin{array}{c}0,098^{* * *} \\
(0,011)\end{array}$ \\
\hline Kriz_likid_kit & & & & & $\begin{array}{c}-0,462^{* *} \\
(0,211)\end{array}$ & & \\
\hline Kriz_küçük_firma & & & & & & $\begin{array}{l}-0,001 \\
(0,001)\end{array}$ & \\
\hline Kriz_küçük_likid_kıt & & & & & & & $\begin{array}{c}-0,657^{* *} \\
(0,303)\end{array}$ \\
\hline Yıl Kukla & Evet & Evet & Evet & Evet & Evet & Evet & Evet \\
\hline Sabit & Evet & Evet & Evet & Evet & Evet & Evet & Evet \\
\hline $\mathrm{R}^{2}$ & 0,060 & 0,061 & 0,061 & 0,061 & 0,061 & 0,061 & 0,061 \\
\hline Prob $>\mathrm{F}$ & 0,000 & 0,000 & 0,000 & 0,000 & 0,000 & 0,000 & 0,000 \\
\hline
\end{tabular}


Diğer taraftan normal dönemlerde düşük likiditeli firmalar, sütun 2'de görüldüğü üzere, vadeyi uzatmakta ve nispeten daha geç ödeme yapmaktadırlar. Aynı etki, sütun 3'te, nakit kıtlığı içindeki küçük firmalarda daha belirgindir. Dolayısıyla kısa vadeli likiditenin varlığı kullanılan kredinin vadesine doğrudan etki edebilmektedir. Tedarikçi firma ortak menfaatler çerçevesinde alıcıyı desteklemekte ve bu süreçte borçlu firmanın daha geç ödeme yapmasını kabul etmiş durumdadır. Diğer taraftan küçük firma değişkeni anlamlı bir sonuç doğurmamıştır. Kriz kukla değişkeni pozitif ve anlamlı bir katsayıya sahiptir buda bu dönemde firmaların genel olarak ticari borçlarını daha kısa sürede ödediklerini gösterir. Nakit akışlarındaki daralmanın firmaların ticari alacaklarını daha kısa sürede tahsil etmeye zorladığı bu nedenle de borçların vadesinin kısaldığı değerlendirilmektedir.

Diğer taraftan kriz dönemlerinde likidite kıtlığının süreyi uzatıcı etkisi sütun 5 ve 7 'de gösterilmiştir. Hem düşük likiditeli hem de düşük likiditeli küçük firmalar ticari borçlarını daha geç ödemektedirler. Genel olarak kredi borçları kriz dönemlerinde daha erken tahsil edilmiş olsa da firmadaki likidite kıtlığı tedarikçi firma tarafından tolere edilmekte ve alacakların vadesi uzatılmaktadır. Dolayısıyla TK'ler gelişmiş ülkelerde bile alternatif bir finansman kaynağı olarak rol almaktadır. Tablo 7 gelişmekte olan ülke firmaların ticari borç ödeme sürelerindeki değişim sonuçlarını göstermektedir. Firma bazlı değişkenler göz önüne alındığında gelişmiş ülke firmalarıyla benzer sonuçlar elde edilmiştir.

Tablo 7. Küçüklük ve Likidite Etkisi (Gelişen Ülkeler)

\begin{tabular}{|c|c|c|c|c|c|c|c|}
\hline \multicolumn{8}{|c|}{ Bağımlı Değişken: Ticari Kredi Kullanım Süresi } \\
\hline & 1 & 2 & 3 & 4 & 5 & 6 & 7 \\
\hline Nakit & $\begin{array}{c}0,441 * * * \\
(0,091)\end{array}$ & $\begin{array}{c}0,437 * * * \\
(0,091)\end{array}$ & $\begin{array}{c}0,415^{* * *} \\
(0,091)\end{array}$ & $\begin{array}{c}0,434^{* * *} \\
(0,091)\end{array}$ & $\begin{array}{c}0,434^{* * *} \\
(0,091)\end{array}$ & $\begin{array}{c}0,426 * * * \\
(0,091)\end{array}$ & $\begin{array}{c}0,423 * * * \\
(0,091)\end{array}$ \\
\hline Maddi duran & $\begin{array}{l}0,109^{*} \\
(0,058)\end{array}$ & $\begin{array}{l}0,110^{*} \\
(0,058)\end{array}$ & $\begin{array}{l}0,110^{*} \\
(0,058)\end{array}$ & $\begin{array}{l}0,109 * \\
(0,058)\end{array}$ & $\begin{array}{l}0,109^{*} \\
(0,058)\end{array}$ & $\begin{array}{l}0,111^{*} \\
(0,058)\end{array}$ & $\begin{array}{l}0,112^{*} \\
(0,058)\end{array}$ \\
\hline Borç & $\begin{array}{c}0,130 * * * \\
(0,047)\end{array}$ & $\begin{array}{c}0,130^{* * *} \\
(0,047)\end{array}$ & $\begin{array}{c}0,129 * * * \\
(0,047)\end{array}$ & $\begin{array}{c}0,132^{* * *} \\
(0,047)\end{array}$ & $\begin{array}{c}0,132^{* * *} \\
(0,047)\end{array}$ & $\begin{array}{c}0,129 * * * \\
(0,047)\end{array}$ & $\begin{array}{c}0,130 * * * \\
(0,047)\end{array}$ \\
\hline Hacim & $\begin{array}{c}-0,043 * * * \\
(0,013)\end{array}$ & $\begin{array}{c}-0,050^{* * *} \\
(0,013)\end{array}$ & $\begin{array}{c}-0,045^{* * *} \\
(0,013)\end{array}$ & $\begin{array}{c}-0,041^{* * *} \\
(0,013)\end{array}$ & $\begin{array}{c}-0,042^{* * *} \\
(0,013)\end{array}$ & $\begin{array}{c}-0,042^{* * *} \\
(0,013)\end{array}$ & $\begin{array}{c}-0,042^{* * *} \\
(0,013)\end{array}$ \\
\hline Kârlılık & $\begin{array}{c}0,131 * * \\
(0,066)\end{array}$ & $\begin{array}{c}0,132^{* *} \\
(0,066)\end{array}$ & $\begin{array}{c}0,131^{* *} \\
(0,066)\end{array}$ & $\begin{array}{c}0,130 * * \\
(0,066)\end{array}$ & $\begin{array}{c}0,130^{* *} \\
(0,066)\end{array}$ & $\begin{array}{c}0,130^{* *} \\
(0,066)\end{array}$ & $\begin{array}{l}0,129^{*} \\
(0,066)\end{array}$ \\
\hline Verimlilik & $\begin{array}{c}0,404 * * * \\
(0,021)\end{array}$ & $\begin{array}{c}0,405^{* * *} \\
(0,021)\end{array}$ & $\begin{array}{c}0,403^{* * *} \\
(0,021)\end{array}$ & $\begin{array}{c}0,403^{* * *} \\
(0,021)\end{array}$ & $\begin{array}{c}0,403^{* * *} \\
(0,021)\end{array}$ & $\begin{array}{c}0,403 * * * \\
(0,021)\end{array}$ & $\begin{array}{c}0,403 * * * \\
(0,021)\end{array}$ \\
\hline Nakit_kit & & $\begin{array}{l}-0,577 \\
(0,484)\end{array}$ & & & & & \\
\hline Küçük_firma & & $\begin{array}{c}-0,004^{* *} \\
(0,029)\end{array}$ & & & & & \\
\hline Küçük_nakit_kıt & & & $\begin{array}{c}0,044 \\
(0,757)\end{array}$ & & & & \\
\hline Yavaş & & & & $\begin{array}{c}-0,041^{* * *} \\
(0,011)\end{array}$ & $\begin{array}{c}-0,038 * * * \\
(0,011)\end{array}$ & $\begin{array}{c}-0,038^{* * *} \\
(0,011)\end{array}$ & $\begin{array}{c}-0,033 * * * \\
(0,011)\end{array}$ \\
\hline Yavaş_küçük_firma & & & & & $\begin{array}{c}-0,001 \\
(0,575)\end{array}$ & & \\
\hline Yavaş_nakit_kıt & & & & & & $\begin{array}{c}2,364 * * \\
(1,017)\end{array}$ & \\
\hline Yavaş_küçük_nakit_kıt & & & & & & & $\begin{array}{c}0,592 \\
(1,600)\end{array}$ \\
\hline Yıl Kukla & Evet & Evet & Evet & Evet & Evet & Evet & Evet \\
\hline Sabit & Evet & Evet & Evet & Evet & Evet & Evet & Evet \\
\hline $\mathrm{R}^{2}$ & 0,086 & 0,086 & 0,086 & 0,086 & 0,086 & 0,086 & 0,086 \\
\hline Prob $>\mathrm{F}$ & 0,000 & 0,000 & 0,000 & 0,000 & 0,000 & 0,000 & 0,000 \\
\hline
\end{tabular}

Zira firmaların likidite seviyesi, yani borç ödeyebilme kapasitesini belirleyen unsurlar örneğin kasa mevcudu, kârlılık ve finansal borçlar TK'leri hızlıca ödemeye imkân tanıyarak vade üzerinde kısaltıcı etkiye neden olmuşlardır. Temel farklılık ise ekonomik daralma yıllarında firmaların genel olarak ödeme süresini 
uzatmış olmalarıdır. Gelişmiş ülkelerin aksine gelişen ülke firmaları bu dönemlerde borç ödeme sürelerini daha da uzatmaktadırlar. Daha önce de tartışıldığı gibi, buna finansal sistem ve ona eşlik eden krediye erişebilme imkânları ile iş hayatının bir parçası olan iş kültürünün neden olmuş olabileceği değerlendirilmektedir (bkz. Demirguc-Kunt ve Maksimovic, 2002; Ghoul ve Zheng, 2016). Diğer taraftan küçük firma değişkeni negatif ve \%5 seviyesinde anlamlıdır. Yani küçük firmalar diğer firmalara nazaran TK borçlarını daha geç ödemektedirler. Benzer bir ilişki normal dönemde nakit kıtlı̆̆ı içindeki firmalarda da ortaya çıkmış ancak istatistiksel olarak anlamlı bir sonuç yakalanamamıştır. Aynı değişkenler kriz döneminde incelendiğinde ekonomik teoriye uygun anlamlı sonuçlar çıkmamıştır.

Tablo 8, ekonomik daralma dönemlerinde gelişmiş ülke firmalarının ticari borç sürelerindeki değişimi analiz eden regresyon sonuçlarını göstermektedir. Bu çalışmanın amacı Tablo 6-7'de elde edilen sonuçların güvenilirlik seviyesini artırmaktır. Sütun 1'de görüleceği üzere kukla değişken pozitif bir katsayıya sahiptir. Bu da daralma dönemlerinde firmaların alacaklarını daha kısa sürede tahsil ettiklerinin göstermektedir. Daha önceki sonuçlara benzer olarak, nakit seviyesinin belirleyici bir rol oynadığı sütun 3, 4, ve 5 'te görülmektedir. Nakit değişkeni negatif ve anlamlı bir katsayıya sahiptir. Firmalar, likidite seviyesi düşük müşterilerine verdikleri TK'leri tahsil ederken sabırlı davranmaktadırlar. Diğer taraftan, küçük firma değişkeni anlamlı bir etki yaratmamıştır ancak katsayı ilişkinin yönünün negatif olduğunu yani ticari borçları ödeme süresinin uzadığını göstermektedir. Sonuçlar genel olarak kriz dönemi sonuçları ile uyumludur ve bulguların daralma dönemleri içinde geçerli olduğunu teyit eder niteliktedir.

Tablo 8. Küçüklük ve Likidite Etkisi (Gelişmiş Ülkeler)

\begin{tabular}{|c|c|c|c|c|c|}
\hline \multicolumn{6}{|c|}{ Bağımlı Değişken: Ticari Kredi Kullanım Süresi } \\
\hline & 1 & 2 & 3 & 4 & 5 \\
\hline \multirow[t]{2}{*}{ Nakit } & $0,261 * * *$ & $0,261^{* * *}$ & $0,260 * * *$ & $0,260 * * *$ & $0,255^{* * *}$ \\
\hline & $(0,036)$ & $(0,036)$ & $(0,036)$ & $(0,036)$ & $(0,036)$ \\
\hline \multirow[t]{2}{*}{ Maddi duran } & $0,159 * * *$ & $0,157 * * *$ & $0,166^{* * *}$ & $0,166^{* * *}$ & $0,166^{* * *}$ \\
\hline & $(0,043)$ & $(0,043)$ & $(0,043)$ & $(0,043)$ & $(0,043)$ \\
\hline \multirow[t]{2}{*}{ Borç } & $.053^{* *}$ & $.055^{* *}$ & $.057 * *$ & $.057^{* *}$ & $.057 * *$ \\
\hline & $(0,027)$ & $(0,027)$ & $(0,027)$ & $(0,027)$ & $(0,027)$ \\
\hline \multirow[t]{2}{*}{ Hacim } & $0,033 * * *$ & $0,033 * * *$ & $0,034 * * *$ & $0,034 * * *$ & $0,034 * * *$ \\
\hline & $(0,008)$ & $(0,008)$ & $(0,008)$ & $(0,008)$ & $(0,008)$ \\
\hline \multirow[t]{2}{*}{ Kârlılık } & 0,033 & 0,037 & 0,037 & 0,037 & 0,037 \\
\hline & $(0,027)$ & $(0,027)$ & $(0,027)$ & $(0,027)$ & $(0,027)$ \\
\hline \multirow[t]{2}{*}{ Verimlilik } & $0,279 * * *$ & $0,279 * * *$ & $0,279 * * *$ & $0,279 * * *$ & $0,279 * * *$ \\
\hline & $(0,018)$ & $(0,018)$ & $(0,018)$ & $(0,018)$ & $(0,018)$ \\
\hline \multirow[t]{2}{*}{ Yavaş } & $0,038 * * *$ & $0,038 * * *$ & $0,042^{* * *}$ & $0,042 * * *$ & $0,045^{* * *}$ \\
\hline & $(0,005)$ & $(0,005)$ & $(0,005)$ & $(0,005)$ & $(0,005)$ \\
\hline \multirow[t]{2}{*}{ Yavaş_küçük_firma } & & $-0,001$ & & -.001 & \\
\hline & & $(0,001)$ & & $(.001)$ & \\
\hline \multirow{2}{*}{ Yavaş_nakit_kıt } & & & $-0,570 * * *$ & $-0,570 * * *$ & \\
\hline & & & $(0,209)$ & $(0,209)$ & \\
\hline \multirow[t]{2}{*}{ Yavaş_küçük_nakit_kıt } & & & & & $-0,808 * * *$ \\
\hline & & & & & $(0,299)$ \\
\hline Yıl kukla & Evet & Evet & Evet & Evet & Evet \\
\hline Sabit & Evet & Evet & Evet & Evet & Evet \\
\hline $\mathrm{R}^{2}$ & 0,061 & 0,061 & 0,061 & 0,061 & 0,062 \\
\hline Prob $>\mathrm{F}$ & 0,000 & 0,000 & 0,000 & 0,000 & 0,000 \\
\hline
\end{tabular}

\section{Sonuç}

Literatürdeki mevcut çalışmalardan farklı olarak, bu çalışmada ticari krediler hem miktar hem de vade açısından incelenmiştir. Özellikle ekonomik daralma dönemlerinde satış gelirlerinin azaldığı göz önüne alındığında, ticari kredilerin ödeme sürelerindeki değişimin incelenmesi büyük önem teşkil etmektedir. 
Yöntem olarak sabit etki panel veri analizi metodu benimsenmiştir ${ }^{9}$. Elde edilen bulgular firmaların daralma dönemlerinde daha fazla ticari kredi kullandıklarını ve bu kredilerin vadesinin uzadığını göstermektedir. Ancak bu bulgular, gelişmiş ve gelişmekte olan ülkeler arasında belirgin bir farklılık arz etmektedir. Örneğin söz konusu dönemlerde gelişmiş ülke firmaları TK miktarını azaltırken gelişen ülke firmaları arttırmaktadır. Robustness amaçlı hem daralma hem de kriz dönemlerini kapsayan analizler yapılmış ve elde edilen sonuçların bu bulguyu desteklediği görülmüştür. Buna ek olarak, küçük ve/veya düşük likiditeli firmaların TK politikaları da ayrıca incelenmiştir. Bulgular, nakit darlığının hem normal hem de sıkıntılı dönemlerde her iki grupta da artan TK kullanımı ile sonuçlandığını göstermiştir. Diğer taraftan, gelişmiş ülkelerdeki küçük firmaların TK kullanımı tutar olarak negatif etkilenirken, bu durum gelişmekte olan ülke firmaları için ise tam tersi yöndedir. Normal dönemlerde küçük firmalar nispeten daha fazla TK talep ederken, bu artış sıkıntılı dönemlere yansımamıştır.

Gelişmiş ve gelişen ülkeler arasındaki bir diğer çarpıcı farklılık, TK'lerin vadelerinde ortaya çıkmaktadır. Gelişmiş ülkelerde sıkıntıı dönemlerde TK'ların miktarı ile birlikte vadesi de kısalmış ve firmalar alacaklarını daha kısa sürede tahsil etme yoluna gitmişlerdir. Bunun istisnası ise düşük likiditeli firmalarda olmuştur. Firma küçüklügünün anlamlı bir sonuç doğurmamasına karşın, likidite azlığııın bu süreyi anlamlı bir şekilde uzattığına dair kanıtlar bulunmuştur. Gelişmekte olan ülkelerde ise miktar ile birlikte TK vadeleri anlamlı bir şekilde uzamıştır ve firmalar tedarikçi finansmanından daha uzun süreli olarak faydalanabilmişlerdir. Küçük ve/veya düşük likiditeli firmalar vade konusunda tedarikçilerinden faydalanamamış gibi görünmektedirler, ancak krizin/daralma döneminin vade üzerindeki net marjinal etkisi pozitiftir. Gelişen ve gelişmekte olan ülkelerin arasındaki farkııı̆̆ın ise finansal kredi kıtlığından kaynaklandığı değerlendirilmiştir. Piyasadaki likidite darlığının TK vadeleri üzerinde baskı yarattığı ve yine bu dönemlerde banka kredisine erişimdeki zorlukların bu sonucu doğurduğu değerlendirilmektedir.

Gelişmiş ve gelişen ülke firmalarının arasındaki belirgin farkların pek çok nedeni olabileceği gibi, temel nedenin finansal sistemdeki derinlik (bu konuda bkz. Demirgüç-Kunt ve Maximoviç, 2001; Fisman ve Love, 2003) ve daralma dönemlerinde uygulanan ekonomi politikalarının olduğu tahmin edilmektedir. Sonuç olarak likidite seviyesi ticari borç yönetiminde önemli bir rol oynamakla beraber, çalışmanın bulguları tedarik zincirindeki dayanışmanın önemini de ortaya çıkarmıştır. Bu dayanışmanın temel gerekçesi borçlanıcı ve tedarikçi firmaların nakit akışlarının birbirine bağlı olmasıdır (Cunat, 2007). Dolayısıyla, TK sağlamanın maliyeti gelecekte ondan elde edilecek maddi faydanın üzerine çıkmadığı sürece, tedarikçi firma krediyi vermeye devam edecektir (Garcia-Appendini ve Montroel-Garriga, 2011).

Bu çalışmanın neticesinde literatürdeki benzer çalışmaların bulguları ile hem uyuşan hem de çelişen bulgulara ulaşılmıştır. Örneğin, Mcguinnes vd. (2018) 2008 finansal krizinde TK'lerin rolünü, 13 Avrupa ülkesinde faaliyet gösteren КОВi'ler üzerinde incelemişlerdir. Temel bulgular şirketlerin 2008 krizi ile gelen ekonomik çalkantıdan çıkmalarında TK'lerin önemli bir katkısı olduğunu göstermektedir. Valverde vd. (2016) 2008 krizi sonrasında İspanya'da faaliyet gösteren KOBi'lerin TK'lere alternatif bir finansman aracı olarak yaklaşıp yaklaşmadıklarını incelemişlerdir. Bu süreçte finans sektörünün kredi arzında önemli daralmalar ortaya çıktığını ve bunun neticesinde yabancı kaynağa erişimde zorluk yaşayan firmaların iş ortaklarından daha fazla TK talep ettikleri bulgusuna ulaşmışlardır. Benzer bir çalışmada, Garcia-Appendini ve MontoriolGarriga (2013) kredi arzındaki değişimleri incelemişler ve likiditesi yüksek firmaların iş ortaklarına 2008 finansal krizi gibi sıkıntılı dönemlerde daha fazla TK kullandırdıkları bulgusuna ulaşmışlardır. Dolayısıyla bulgular, ağırlıklı olarak TK kullanımının arttığı yönündedir. Bu çalışma, kullanılan verilerin halka açık firmalara ait olması nedeniyle, Mcguinnes vd. (2018) ve Valverde vd. (2016)'den ayrılmaktadır. Garcia-Appendini ve Montoriol-Garriga (2013)'in bulguları ile kıyaslandığında ise, firmaların ekonominin sıkıntıya düştüğü dönemlerde iş ortaklarıyla dayanışma içerisine girdiği bulgusuyla ortak bir noktada buluşmaktadır.

Buna rağmen pek çok çalışmada (örneğin; Fisman ve Love, 2003; Kim ve Choi, 2003; Atanasova ve Wilson, 2003) dile getirilen TK'lerin alternatif bir finansal kaynak olma niteliği ile uyuşmayan bulgular da elde edilmiştir. Bu çalışmalarda genel olarak finansal krediye erişimin güçleştiği dönemlerde firmaların TK talebini arttırdığı yönünde ampirik kanıtlar sunulmasına karşın, gelişmiş ülkelerde özellikle 2008 finansal krizinin ve ekonomik daralmanın TK kullanımını hacimsel olarak negatif etkilediği görülmüştür. Diğer taraftan gelişmiş ülke firmalarının TK kullanım sürelerinin de daralma dönemlerinde belirgin bir şekilde azaldığı gözlenmiştir. 
Elbette kullanılan veri setindeki firmaların finansal yapısı, krediye erişim imkânları ve incelenen dönemlerdeki ekonomik özelliklerin farklı oluşu bulguların örtüşmemesinin nedenleri olabilecektir. Mevcut literatürle uyumlu bulgular ise gelişen ülke firmaları ile yapılan analizlerde elde edilmiştir. Sıkıntılı dönemlerde firmalar TK miktarını ve vadesini arttırmışlardır.

Bu çalışmanın amacı alternatif bir finansman aracı olarak kabul edilen ticari kredilerin ekonominin sıkıntıya düştüğü dönemlerde firmalar açısından ne tür bir rol üstlendiğini ortaya koymaktır. Bulgular, içinde bulunduğumuz pandemi süreci gibi sıkıntılı dönemlerde TK'lerin süreci kolaylaştırıcı bir rol oynayabileceğini göstermektir. Tedarikçi firmalar kendilerinden mal alanlara sundukları TK'lerin miktarını arttırıp vadesini uzatarak finansal açıdan onlara kolaylık tanımış olmaktadırlar. Pandemi süreci ekonomik aktivitedeki yavaşlamanın etkisiyle firmaların nakit akışlarını olumsuz etkileyecek ve firmaların likidite oranlarını aşağıya çekecektir. Özellikle bu süreci atlatmaya yetecek kadar nakit stoğu olmayan firmaların sıkıntıya düşmesi beklenebilir. Daha önceki ampirik çalışmalarda da dile getirildiği gibi ortak menfaatler çerçevesinde oluşacak firma dayanışması, bu süreci kolay atlatma noktasında ihtiyaç duyulan kısa vadeli likiditeyi sağlayabilir. Dolayısıyla firmalar bu tür dönemlerde geleneksel banka kredisi yerine alternatif finansal kaynaklara, örneğin ticari kredilere yönelebilirler.

\section{Beyan ve Açıklamalar (Disclosure Statements)}

1. Bu çalıșmanın yazarı, araştırma ve yayın etiği ilkelerine uyduğunu kabul etmektedir (The author of this article confirms that her work complies with the principles of research and publication ethics).

2. Yazar tarafından herhangi bir çıkar çatışması beyan edilmemiştir (No potential conflict of interest was reported by the author).

3. Bu çalışma, intihal tarama programı kullanılarak intihal taramasından geçirilmiştir (This article was screened for potential plagiarism using a plagiarism screening program).

\section{Son Notlar}

1. Ekonomik daralma ifadesi GSMH'deki küçülmeyi temsilen kullanılmıştır.

2. Hukuki ve finansal yapının ticari kredi kullanımına etkisi için bkz. Demirguc-Kunt ve Maksimovic (2002) ve Ghoul ve Zheng (2016).

3. 2000-2014 yılları arasında her ülkenin GSMH'sindeki en küçük büyümenin gerçekleştiği üç yıl daralma dönemlerini ifade etmektedir. Bu dönemlerdeki büyüme rakamlarının büyük çoğunluğu negatif olduğu için "daralma" ifadesi kullanılmıştır.

4. "Financial accelerator" kavramı özünde para politikasının reel sektöre etkilerini tarif etmek üzere ortaya atılmış olsa da ekonomik küçülme dönemleri reel sektörün finansman imkânları açısından değerlendirildiğinde konseptin uygun olduğu görülecektir.

5. Ticari borçların vadesini inceleyen çalışmalardan bazıları Deloof ve Jegers (1996) ve Bastos ve Pindado (2013)'dır.

6. Benzer bir prosedür için bkz. Kilic vd. (2020).

7. Bu işlem sadece analizde kullanılan bilanço kalemleri için geçerlidir.

8. Gelişmiş ve gelişen ülkelerde için belirlenen $\% 10$ ve $\% 5$ eşik değerler $\frac{\text { nakit }_{i j t}}{\text { Dönen Varllklar }{ }_{i j t}}$ 'in ortanca değerleridir.

9. Sabit etki panel veri analizi yöntemi ile firmalarda ticari borçların incelendiği bazı çalışmalar için bkz. Mateut vd. (2006); Garcia-Appendini ve Montoriol-Garriga (2011); Abdulla vd. (2017).

\section{Kaynaklar}

Abdulla, Y., Dang, V. A., \& Arif, K. (2017). Stock market listing and the use of trade credit: Evidence from public and private firms. Journal of Corporate Finance, 46(3), 391-410. 
Agostino, M., \& Trivieri, F. (2014). Does trade credit play a signaling role? Some evidence from SMEs microdata. Small Business Economics, 42(1), 131-151.

Atanasova, C, V., \& Wilson, N. (2003). Bank borrowing constraints and the demand for trade credit: Evidence from panel data. Managerial and Decision Economics, 24(6/7), 503-514.

Bastos, R., \& Pindado, J. (2013). Trade credit during a financial crisis: A panel data analysis. Journal of Business Research, 66, 614-620.

Beck, T., Demirgüç-Kunt, A., \& Maximovic, V. (2005). Financial and legal constraints to growth: Does firm size matter? Journal of Finance, 60(1), 137-177.

Bernanke, B., Gertler, M., \& Gilchrist, S. (1996). The financial accelerator and the flight to quality. The Review of Economics and Statistics, 78(1), 1-15.

Bernanke, B., \& Gertler, G. (1995). Inside the black Box: The credit channel of monetary policy transmission. The Journal of Economic Perspectives, 9(4), 27-48.

Biais, B., \& Gollier, C. (1997). Trade credit and credit rationing. The Review of Financial Studies, 10 (4), $903-937$.

Brooks, C. (2014). Introductory econometrics for finance. Cambridge University Press.

Calomiris, C., Himmelberg, C., \& P. Wachtel, (1995). Commercial paper, corporate finance, and the business cycle: A microeconomic approach. Carnegie-Rochester Series on Public Policy, 42, 203-250.

Chenga, N. S., \& Richard, P. (2003). The trade credit decision: Evidence of UK firms. Managerial Decision Economics, 24, 419-438.

Choi, W. G., \& Kim, Y. (2005). Trade credit and the effect of macro-financial shocks: evidence from U.S. panel data. Journal of Financial and Quantitative Analysis, 40, 897-925.

Choi, I. (2001). Unit root tests for panel data. Journal of International Money and Finance, 20, 249-272.

Cunat, V. (2007). Trade credit: Suppliers as debt collectors and insurance providers. The Review of Financial Studies, 20(2), 491-527.

Danielson, M. G., \& Scott, J. A. (2004). Bank loan availability and trade credit demand. The Financial Review, 39(4), 579600.

de Haas, R., \& van Lelyveld, I. (2010). Internal capital markets and lending by multinational bank subsidiaries. Journal of Financial Intermediation, 19(1), 1-25.

Deloof, M., \& Jegers, M. (1996). Trade credit, product quality, and intragroup trade: Some European evidence. Financial Management, 25(3), 33-43.

Demirgüç-Kunt, A., \& Maksimovic, V. (2001). Firms as financial intermediaries: Evidence from trade credit data. World Bank Policy Research Working Paper.

Fabbri, D., \& Klapper, L. F. (2016). Bargaining power and trade credit. Journal of Corporate Finance, 41(4), 66-80.

Fisman, R., \& Love, I. (2003). Trade credit, financial intermediary development, and industry growth. J. Financ., 58, 353374.

Frank, M., \& Maksimovic, V. (1998). Trade credit, collateral, and adverse selection. UBC Working Paper.

Garcia-Appendini, M. E., \& Montoriol-Garriga, J. (2011). Firms as liquidity providers: Evidence from the 2007-2008 financial crisis. Journal of Financial Economics, 109(1), 272-291

Ghoul, S., \& Zheng, X. (2016). Trade credit provision and national culture. Journal of Corporate Finance, 41(3), $475-501$.

Huang, H., Shi, X., \& Zhang, S. (2011). Counter-cyclical substitution between trade credit and bank credit. Journal of Banking \& Finance, 35(8),1859-1878.

Karakoç, B. (2020). Trade credit and bank financing: A substitute or a complement. In H. Babacan \& Y. A. Unvan (Ed.), Academic studies in economics and administrative sciences (pp: 115-140). IVPE Publishing.

Kazmin, A., Lamont, J., \& Leahy J. (2008, Kasım 17). India in emergency step to unblock trade credit. Financial Times, p.3.

Kilic, S., Delikanli I., \& Alp, A. (2020). Yabancı yatırımcı sahipliği oranındaki değişimin getiri, volatilite ve likidite üzerindeki etkisi: BIST GYO sektörü için panel veri analizi. Business and Economics Research Journal, 11(2), 397-411.

Mateut, S., Bougheas S., \& Mizen, P. (2006). Trade credit, bank lending and monetary policy transmission. European Economic Review, 50(3), 603-629.

Meltzer, A. (1960). Mercantile credit, monetary policy, and size of firms. Review of Economics and Statistics, 42(4), 29437. 
Mian, S. L., \& Smith, C. W. (1992). Accounts receivable management policy: Theory and evidence. Journal of Finance, 47(1), 169-200.

Nilsen, J. (2002). Trade credit and the bank lending channel. Journal of Money, Credit and Banking, 34(1), $226-253$.

$\mathrm{Ng}, \mathrm{C}$., Smith, J., \& Smith, R. (1999). Evidence on the determinants of credit terms in interfirm trade. Journal of Finance, 54, 1109-29.

Petersen, M. A., \& Rajan, R. G. (1997). Trade credit: Theories and evidence. Review of Financial Studies, 10 (3), 661-691.

Popov, A., \& Udell, G. F. (2012). Cross-border banking, credit access, and the financial crisis. Journal of International Economics, 87(1),147-161.

Presbitero, A., Udell, G. F., \& Zazzaro, A. (2011). Bank organizational structure and the credit crunch. University of Ancona Working Paper.

StataCorp., (2019). Stata 16 base reference manual. College Station, TX: Stata Press.

Schwartz, R. A. (1974). An economic model of trade credit. Journal of Financial and Quantitative Analysis, 9(4), $643-657$. 


\section{Ekler}

Ek 1. Fisher Birim Kök Testi

HO: Serilerde birim kök vardır (durağan değildir)

\begin{tabular}{lcccc}
\hline \multirow{2}{*}{ Değişken } & \multicolumn{2}{c}{ Gelişmiş ülke verileri } & \multicolumn{2}{c}{ Gelişen ülke verileri } \\
Chi-Sq. İstatistiği & Prob & Chi-Sq. İstatistiği & Prob \\
\hline Tticari kredi & 25,700 & 0,000 & 12,900 & 0,000 \\
Nakit & 25,600 & 0,000 & 14,700 & 0,000 \\
Duran & 23,900 & 0,000 & 11,200 & 0,000 \\
Borç & 25,500 & 0,000 & 12,800 & 0,000 \\
Hacim & 24,900 & 0,000 & 13,000 & 0,000 \\
Kârlılık & 28,200 & 0,000 & 12,800 & 0,000 \\
Verimlilik & 24,100 & 0,000 & 11,600 & 0,000 \\
\hline
\end{tabular}

Ek 2. Hausman Test Sonuçları

-Gelişmiş Ülke Verileri-

Katsayılar

\begin{tabular}{lcccc}
\hline & (b) & $(\mathrm{B})$ & $(\mathrm{b}-\mathrm{B})$ & \\
& Sabit & Rassal & Fark & Hata terimi \\
\hline Nakit &,- 0488791 & $-0,0496408$ & 0,000762 & 0,000523 \\
Maddi duran & $-0,0439554$ & $-0,0470797$ & 0,003124 & 0,00102 \\
Borç & $-0,0110921$ & $-0,0136592$ & 0,002567 & 0,000414 \\
Hacim &,- 007269 &,- 0029021 & $-0,00437$ & 0,000263 \\
Kârlılık & $-0,0545676$ & $-0,0596561$ & 0,005089 & 0,000348 \\
Verimlilik & 0,056124 & 0,0601539 & $-0,00403$ & 0,000226
\end{tabular}

HO: kalıntılar ile açıklayıcı değişkenler arasındaki korelasyon 0 'dır.

Chi-Sq. İstatistiği 461,89 Prob. 0,000

-Gelişen Ülke Verileri-

Katsayılar

\begin{tabular}{lcccc}
\hline & (b) & $(\mathrm{B})$ & $(\mathrm{b}-\mathrm{B})$ & \\
& Sabit & Rassal & Fark & Hata terimi \\
\hline Nakit & $-0,0450871$ & $-0,0473999$ & 0,002313 & 0,001811 \\
Maddi duran & $-0,0392385$ & $-0,0521267$ & 0,012888 & 0,001518 \\
Borç & $-0,042035$ & $-0,038474$ & $-0,00356$ & 0,001039 \\
Hacim & $-0,0022246$ & $-0,0022038$ & $-0,00001$ & 0,000543 \\
Kârlılık & $-0,0687729$ & $-0,0801326$ & 0,01136 & 0,001009 \\
Verimlilik & 0,0385102 & 0,0443139 & $-0,0058$ & 0,000482 \\
\hline
\end{tabular}

HO: Katsayılar arasındaki farklar sistematik değildir.

$\begin{array}{lll}\text { Chi-Sq. İstatistiği } & \text { 256,67 } & \text { Prob. }\end{array}$ 